\title{
The Products and Market Strategies of the Osaka Cotton Spinning Company: 1883-1914
}

By Matao Miyamoto

Osaka University

The Osaka Cotton Spinning Company (Osaka Boseki Kaisha), established in May of 1882, is known as the first mechanized cotton spinning enterprise in Japan to become an entrepreneurial success. The introduction of steam power, the implementation of night work and a double-shift system, the processing of foreign cotton, the dispatch of technicians for training abroad, as well as the use of the jointstock company type of organization and so on, all made it the model for the many cotton spinning enterprises which were set up after the latter half of the 1880 s as the hub of the new Osaka cotton spinning industry.

When we consider whether Osaka Boseki maintained its superiority as a vanguard enterprise throughout the period from its inauguration to its amalgamation in 1914 with the Mie Cotton Spinning Company to become the Toyo Cotton Spinning Company (Toyo Boseki), however, our answer must be in the negative. As can be discerned in Figures 1 to 3 , Osaka Boseki did have a period of remarkably high earnings in the years after its establishment, but after the latter half of the 1890s, in such areas as profitability, growth and market share, it was often behind other major spinning companies. Why did this stagnation and blunting of the growth of the Osaka Cotton Spinning Company come about? This paper will consider the problem from the point of view of the company's products and market strategies (Figures 1,2,3).

\section{The Products and Markets of Osaka Boseki at its Inception}

After the establishment of the company and up to about 1890 , the Osaka Cotton Spinning Company produced cotton thread of counts between 10 and 20 , with most of the yarns around no. $14 .{ }^{1}$ One of the main reasons for concentrating on coarse yarns was the constraint imposed by the use of indigenous raw cotton. According to Katsumasa Okamura, one of Osaka Boseki's first technicians, "When the 1884 Competitive Exhibition for Cotton Yarn was held, Osaka Boseki wanted to display a yarn produced from Japan's best cotton, Sakajo, but found that thread finer than no. 17 count could not be produced from the indigenous cotton." 
Figure 1 Rates of Return on Total Assets for Five Major Spinning Companies
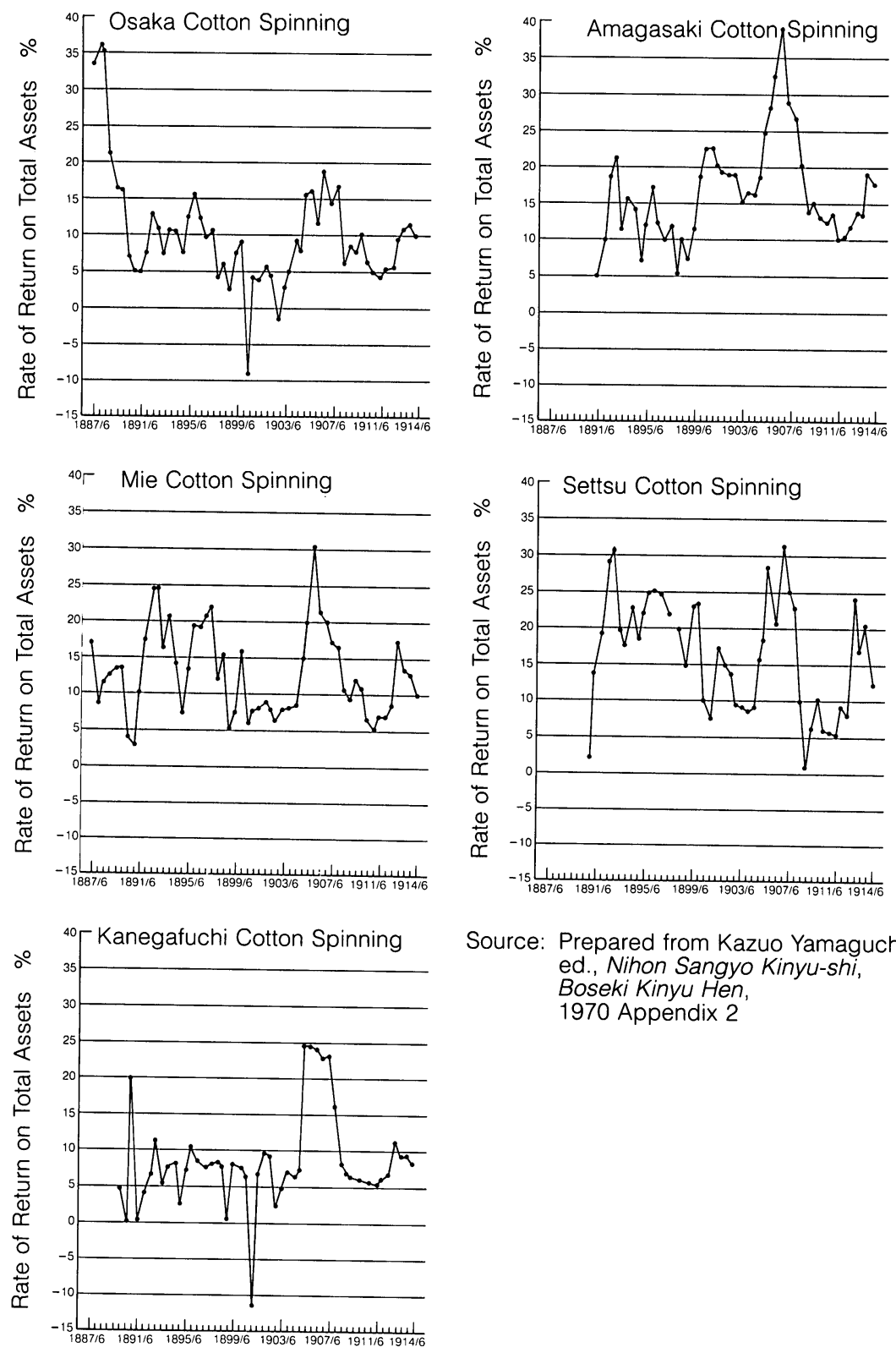

Source: Prepared from Kazuo Yamaguchi, ed., Nihon Sangyo Kinyu-shi, Boseki Kinyu Hen, 1970 Appendix 2 
Figure 2 Osaka Boseki's Yarn Output and Its Share in National Production
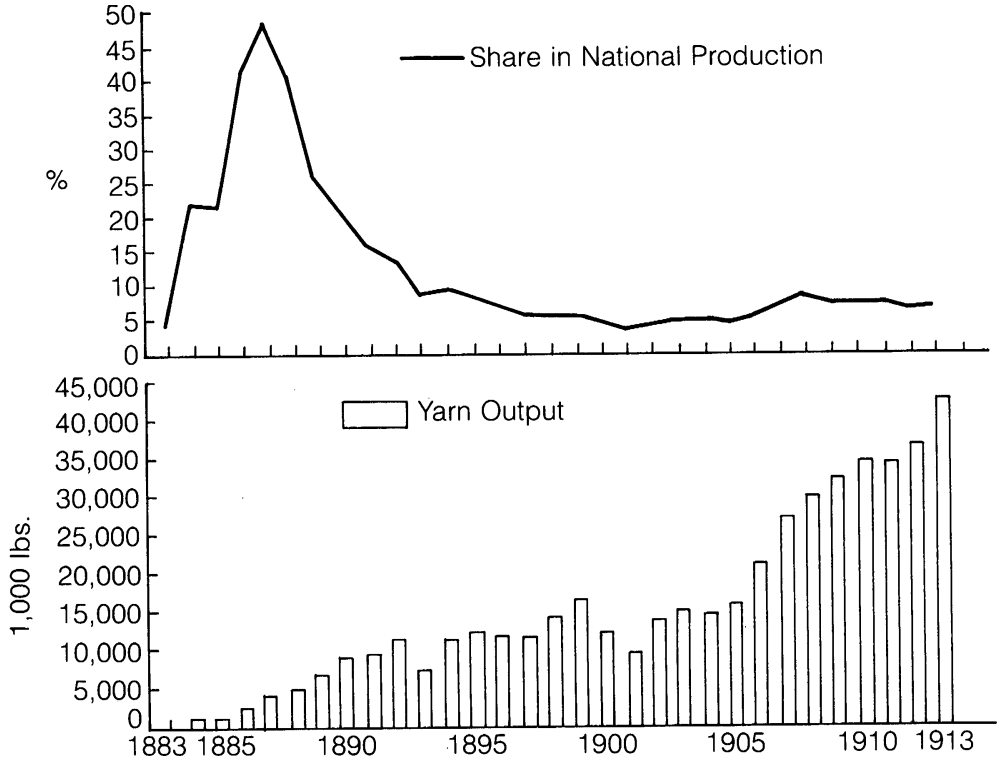

Source: Prepared from Osaka Boseki Kokajo

Figure 3 Osaka Boseki's Cloth Output and Its Share in National Production
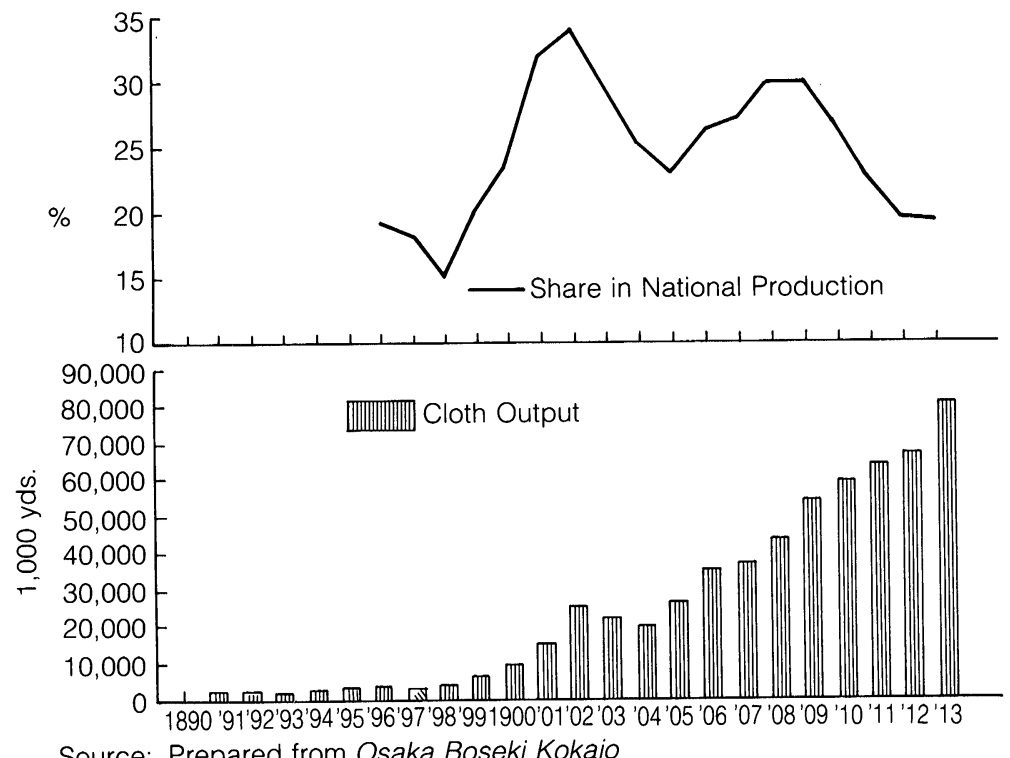
But an even more crucial reason why coarse yarns became the most common product was the popular demand for them. On the grounds that the thick hand-woven cloths currently being produced from handreeled yarns made from indigenous cotton were superior in durability and toughness, and were easy to dye (particularly with indigo), such heavier cloths retained their popularity. Even though the grey shirting imported from England was cheaper than Japanese-made cotton cloth, they were considered too thin and lacking in durability and were labelled "the inferior product." It is said that in order to compensate for the lack of substance in the grey shirting, known as ki-kanakin, sizing was added to give it more thickness before it was sold. ${ }^{3}$ Because at the time the main demand for cotton fabrics was for thicker cloths, the demand for the material of cloths also consisted mainly of thicker threads. Of yarns imported between 1878 and 1883, 70\% were Indian and English yarns between counts of 16 and $24 .{ }^{4}$ At the Cotton Yarn Consultative Meeting in June of 1885 (where an exchange of information on problems of management and technology took place among spinning companies), the following statement by Akitoshi Monden, representative of Osaka Boseki, showed that the company had correctly analyzed this current consumption pattern.

If an enterprise does not make a profit, it will not be a success. In order to make a profit, it must produce coarse yarns with counts between 10 and 20 which are most in demand. Because Japanese raw cotton is of short fiber, moreover, it is not easy to spin fine yarns from it. Therefore, we first should put our efforts into preventing the influx of heavy yarns among cotton yarn imports. Then if we make ourselves capable of producing more of them than will be needed in Japan, we can expect to send the surplus abroad. As spinning machines are very good, the production of fine yarns is possible, but in Japan's present situation the profitability of such production is not assured. For the time being, Japan's spinning industry must concentrate on cheap production of the heavy yarns for which there is a prospect of heavy demand. ${ }^{5}$

Next, let us look at the destination of products in the initial stage of the Company's operations. Sequential versions of the Business Report of Osaka Boseki state:

The largest sales volume goes to Tokyo, and Owari (around Nagoya), Osaka and Echigo (Niigata) follow in that order. Tokyo 
has an associated weaving region comprising the surrounding districts and the Tohoku (Northeast) region, and has good prospects for sales in the future. As they usually use fine yarns for the warp in cotton cloths in the Owari region, our company's yarns go well with them, and there can be no doubt this is another promising market. In the Osaka area market, demand from weaving establishments of the Kawachi and Izumi districts and the flannel makers of Kishu (Wakayama) is not small, but as they often use cheap hand-spun yarns and are not familiar with machine-spun yarns and, moreover, the number of spinning establishments is large and the competition is fierce, markets are constrained. As the Echigo region is one in which the demand for cotton yarn has been large, we are planning to expand our market there. We are not yet selling our products in Shikoku or Kyushu.

(Latter half of 1883)

In this period, our largest sales volumes were in the same regions as in the last period, but markets with good prospects are being opened as well in Akita, Morioka, Iyo (Ehime) and Ecchu (Toyama Pref.)

(First half of 1884)

In this period, our largest sales volumes were in the same regions as previously. But in every region, the demand for our company's yarns are steadily increasing and markets are consequently expanding. In particular, the demand from districts in which we have good prospects such as those of Kishu cotton flannel weavers and the cotton coating (kokura) weavers of Army uniform material has increased conspicuously.

(Latter half of 1884)

New sales outlets have been opened in areas such as Kurume, Kumamoto and Saga (all in Kyushu). At present, demand is not large, but in future these regions will probably become important markets.

(First half of 1885)

Again, at the afore-mentioned Cotton Consultative Meeting, Akitoshi Monden described variations in the regional patterns of demand as follows:

Osaka Boseki's products are sold $40 \%$ to Tokyo, $15 \%$ to Nakajimagun (district) in Owari, $10 \%$ to Niigata in Echigo, $10 \%$ to 
Wakayama in Kishu, and the remaining $25 \%$ to various other districts. In types of yarn, Tokyo takes mainly counts of 14 , Nakajimagun those around 20, Niigata 12 and 13, other districts those from 14 to 16 , and Wakayama those from nos. 8 to $10 .^{6}$

To summarize the above, the Osaka Cotton Spinning Company found its early sales outlets in Tokyo, Owari, Osaka, Tohoku, Echigo and Wakayama, and gradually expanded to markets in Shikoku and Kyushu. And as we can see from the above quotations, the major sales were not in Osaka and western Japan, but rather in Tokyo, Owari, Tohoku and the Hokuriku regions. Such a market structure was apparently foreseen before the beginning of operations, and at the formation of Osaka Boseki, the organizer of the company, Eiichi Shibusawa, appealed to major cotton yarn and cloth merchants of Tokyo for their cooperation in establishing the company. It can be supposed that Shibusawa expected to secure the Tokyo region market with the participation of these cotton merchants. And, from the above analysis, it can be concluded that within a few years after the company's inauguration, his plan had to some extent been fulfilled.

Next, concerning the nature of the cloths in which Osaka Boseki's cotton yarn was used as source material for weaving, Akitoshi Monden stated:

Because the price of indigenous mechanically-spun cotton yarn is high, it is not appropriate as yarn for traditional bleached cottons (shiro-momen), but for striped cotton (shima-momen), a kind of dyed cotton cloth. Although it is more expensive than imported yarn, it is desirable because of its superiority in dyeability ${ }^{7}$

That the main market for Osaka Boseki's cotton yarn was as a raw material for striped cotton is clear from the fact that the sales outlets were Fukushima and Niigata for indigo dyed cloth, Echigo striped-cotton weaving centers, Nakajima-gun in Owari for an area producing striped cotton, and Kurume and Iyo for tie-dyed fabrics (kasuri).

At that time, with the yarns of Osaka Boseki among them, machinespun Japanese yarns could not compete in price with English and Indian yarns in the market acquiring them for bleached cottons, but in the market supplying yarns for striped cottons, they were superior to hand-spun and gara (gara was a primitive spinning machine newly invented by a Japanese technician in the early Meiji period) throstlespun yarns in price and to imported yarns in their dyeability. 


\section{Intensification of Competition in the Market for Coarse Yarn and the Production of No. 20 Cotton Z-Twists}

As noted above, in its early stages the Osaka Cotton Spinning Co. specialized in the production of especially coarse cotton yarn from which dyed cotton fabric could be made, and the distribution routes to its main markets such as Tokyo, Aichi, Tohoku, Echigo and Wakayama were not tied to existing channels centering on Osaka and Tokyo. Osaka, where the company was established, had been a distributing center for cotton goods since the Edo period (1600-1868), and in the 1884 Kogyo Iken (Opinion on Industry - sometimes known as Japan's first Economic White Paper) it was stated that "Osaka is an ideal location for cotton-spinning plants from the point of view of various factors such as production, transport, financing, product marketing and the procurement of labor." 8 But Osaka Boseki, at least in the product marketing field, did not reap the full advantages of its location in Osaka.

Whatever the situation, shunning the market for medium and fine yarns in which competition from imported yarns was occurring, and making a success of the strategy by which the Japanese mechanized spinning industry made a target of markets hitherto cornered by the traditional hand-spun and garabo yarns, Osaka Boseki enjoyed the profits of large-scale production and garnered remarkable results. Sparked by its success, from the end of the 1880s spinning companies sprang up one after the other and because they, like Osaka Boseki, manufactured the thicker yarns, market competition gradually became fiercer.

As a result of the boom in the formation of cotton spinning establishments, the number of spindles increased 3.6 times in only three years from 1890 to 1893 . With reference to the effect which this boom in the formation of spinning enterprises had on existing spinning companies, particularly Osaka Boseki, the Rengo Boseki Geppo (Associated Spinners' Monthly) of August 1889 had the following to say.

Speaking of spinning companies in Japan, Osaka Boseki and Dojima Boseki are the pioneering enterprises, and their products have been selling well, at good prices, so that they have made considerable profits. But in the last three years, many new spinning companies have been established, so that compared with the good price of last year, this year's price for cotton yarn has fallen about 20 yen per $400 \mathrm{lbs}$. With respect to coarse yarns around no. 16 count, 
however, there has been a recent tendency in all textile districts to replace imported with indigenous yarns, so that the market for home-made cotton yarn is expanding and the spinning business is doing well. But something which will no doubt bring about a big change in the market will be the beginning of operations of the Kanegafuchi Cotton Spinning Company (Kanegafuchi Boseki-sho - Kanebo) on August 1 of this year. It is reported that Kanegafuchi Boseki will produce $28,000 \mathrm{lbs}$. of cotton yarn in one 24-hour day of operation. Adding the output of the Tokyo Cotton Spinning Company to this gives a total daily product of $40,000 \mathrm{lbs}$. This amount is approximately equal to the weight handled by the cotton-yarn wholesalers of the Tokyo capital district. As a result, when the products of Kanebo and Tokyo Boseki arrive on the market, Osaka Boseki, which has hitherto sent one-third of its output to Tokyo, will lose its market in the Tokyo region. Not only Osaka Boseki, but Mie Boseki and Enshu Boseki (both on the Pacific coast nearer to Tokyo) are in danger of losing markets. ${ }^{9}$

What catches our attention in the above quotation is the fact that it points out that as a result of the establishment of Kanegafuchi Boseki and Tokyo Boseki, the Osaka Cotton Spinning Company, which had been sending one-third of its output of yarn to Tokyo, was facing a "market shutout."

Looking at this effect as described in the Business Report of Osaka Boseki, we find that the Osaka Cotton Spinning Company's output of yarn increased steadily from 1888 to 1890 , but its inventory of yarn based on a standard of 10-15 days' production in 1887-88 was 37 days' product in the latter half of 1889,72 days' in the first half and 85 days' product in the latter half of 1890 . Accounts receivable and raw cotton inventories were also up substantially. As a result of the accumulation of stocks, the sales price of one bale (containing 400lbs.) of yarn fell sharply from 99 yen per bale in September of 1889 to 72 yen in December of $1890 .{ }^{10}$

The competition was not only among Japanese cotton spinning companies, but that with Indian yarn also became intense. Until this time, Indian yarns and Japanese machine-spun yarns had had different markets, but now as well as left-Z-twist yarns, Indian producers began to produce and export yarns of the Japanese S-twist type and because of lowered transport costs, price reductions were achieved and they began to make a concerted assault on the Japanese market for coarse yarns. Between 1886 and 1889, imports of Indian yarn doubled. Because of this, Osaka Boseki also 
suffered a glut in the market for yarns as imports of Indian yarn from August to the early part of October were very large. To deal with this, the Company undertook a reduction in price of cotton yarn.

(Latter half of 1888)

In order to cope with this situation, rather than put all its efforts into competing with other Japanese spinning companies in the market for cotton yarns of dyed cloths, Osaka Boseki adopted a strategy of resisting the influx of Indian yarn by attacking its market in the field of yarn for bleached cottons. Thus the company, with Indian raw cotton imported into Japan for the first time with the help of the 1889 Indian Cotton Inspection Team of Rihei Kawamura and others, began the trial production of no. $20 \mathrm{Z}$-twist cotton yarns, and in the following year, 1890, began full-scale production. The fiber of Indian raw cotton was longer than that of Japanese or Chinese cotton, and not only had the advantage of being easily used in the production of no. 20 Z-twists, but also contributed, because of its cheaper price than the Japanese and Chinese raw materials, to the lowering of costs. The production of no. $20 \mathrm{Z}$-twists by Osaka Boseki was successful, and for the latter half of 1891 the Business Report of Osaka Boseki states that,

Sales of yarn in this period were smooth, and the situation continued in which products could be shipped as soon as they were produced. The competition between indigenous and imported products was intense and the price of yarn low, but the smooth development of the company's sales was the result of its taking the lead and plunging into the production of cotton yarn to replace that from India.

After this, stimulated by the success of Osaka Boseki, other companies also began the production of no. $20 \mathrm{Z}$-twists. Thus, following 1890 the Japanese mechanized spinning industry not only drove out gara frame and hand-spun yarns, but also overwhelmed Indian cotton yarns. Table 1 gives the ratios of various yarns used in the production of bleached cottons handled by the Osaka wholesalers specialized in such cloths, and shows clearly that there was a change from products made from Indian and hand-spun yarns to products made with Japanese machine-spun yarns after 1891 .

In this process, Osaka Boseki reaped the profits of a pioneer with no. $20 \mathrm{Z}$-twists until about the end of 1892 . Comparing the prices of no. 20 twists of the various spinning companies in current issues of the Associated Spinners' Monthly, we can deduce that the price of Osaka Boseki's no. 20 twists was higher than that of other companies and that 
Table 1 Proportions of Various Yarns Used in Bleached Cotton Cloths Handled by Osaka Wholesalers

$\widehat{N}$

\begin{tabular}{ccccc}
\hline & $\begin{array}{c}\text { Japanese } \\
\text { Hand-spun }\end{array}$ & Indian & $\begin{array}{c}\text { Indian \& Japanese } \\
\text { Hand-spun Mixes } \\
\text { (Indian Warps } \\
\text { Japanese Hand- } \\
\text { spun Wefts) }\end{array}$ & $\begin{array}{c}\text { Indian \& Japanese } \\
\text { Machine-spun Mixes } \\
\text { (Indian Warps } \\
\text { Japanese Machine- } \\
\text { spun Wefts) }\end{array}$ \\
\hline 1899 First Half & 6.2 & 90.0 & 3.7 & - \\
Second Half & 3.0 & 94.0 & 3.0 & - \\
1890 First Half & 3.1 & 86.6 & 10.2 & - \\
Second Half & 2.3 & 87.7 & 9.9 & - \\
1891 First Half & 2.7 & 60.4 & 24.0 & 61.0 \\
Second Half & 1.3 & - & - & - \\
\hline
\end{tabular}

Source: Noshomusho (Ministry of Agriculture and Commerce), ed., Nihon Menshi Boseki-gyo Enkaku Kiji

(Records of the Development of the Japanese Cotton Spinning Industry) 
their high quality was appreciated in the market. ${ }^{11}$ And according to the "Table Concerning the State of Business of the Associated Spinning Companies" of May, 1892, Osaka Boseki made no. 20 its average yarn count for ring machines (it was no. 15 for mules.) In comparison, except for Dojima Boseki's no. 20 average, other companies' averages for both ring and mule were less than $20 .{ }^{12}$ Considering that Osaka Boseki's plant was the largest in scale, we can easily imagine that its share of the market for no. 20 cotton yarn was substantial.

In conjunction with the production of no. 20 yarns, changes took place in Osaka Boseki's marketing methods for cotton yarn. ${ }^{13}$ Whereas at its inauguration cotton yarn was sold by special agreement with sales agents in each region, from around 1890 it was sold without discrimination through other outlets as well as the special agents. While this change in marketing methods shows that as a result of Osaka Boseki's participation in the competitive market with imported yarns it was possible to join in the distribution system for imported yarns, for Osaka Boseki it also had the advantage of reducing selling costs. Selling through special contracts to a limited number of special agents tended to make yarn inventories and the burden of accounts receivable larger, but by short-term credit and cash sales that burden was reduced.

At Osaka Boseki, no. $20 \mathrm{Z}$-twist yarn seems to have been given the role of strategic commodity which allowed the company to overcome the serious situation following the 1890 depression. This is apparent from the fact that until about 1895 no. 20 cotton yarn formed a large part of the product at Osaka Boseki. In the fire of December, 1892, Osaka Boseki lost two workshops and more than 30,000 spindles and was obliged to operate with plant reduced by half until the restoration of a 24,000-spindle ring machine in September of 1894. In the interim, the quantity of its yarn product fell to the level of the Settsu, Tenma, Kanegafuchi and Mie Spinning Companies. But even during this time, though the production of no. $20 \mathrm{Z}$-twists was halted, $40-50 \%$ of it was made up by the production of no. $20 \mathrm{~S}$-twists, so that in total production of no. 20 yarn at least, the value of output pulled far ahead of the other companies. ${ }^{14}$

With the completion of fire damage reconstruction in September of 1894, the production of no. $20 \mathrm{Z}$-twists resumed, and as Table 2 shows, the ratio of no. $20 \mathrm{Z}$-twists in the company's total output was $61.7 \%$ in December, 1894, and $54.7 \%$ in December of 1895 . And this meant that in the production of the no. 20 cotton twists, Osaka Boseki's share of industry-wide production was $41 \%$ in 1894 and $26 \%$ in 1895 . And 
Table 2 Consumption of Cotton Yarn Output of the Osaka Cotton Spinning Co.

\begin{tabular}{|c|c|c|c|c|c|c|}
\hline & \multicolumn{2}{|c|}{ Largest Share } & \multicolumn{2}{|c|}{ Second } & \multicolumn{2}{|c|}{ Third } \\
\hline & Count & $\begin{array}{c}\text { Percentage } \\
(\%)\end{array}$ & Count & $\begin{array}{c}\text { Percentage } \\
(\%)\end{array}$ & Count & $\begin{array}{c}\text { Percentage } \\
(\%)\end{array}$ \\
\hline 1893 & No.20S & 47.6 & No.16S & 24.4 & No.18S & 9.8 \\
\hline 1894 & No.20Z & 61.7 & No.16S & 8.1 & No.22Z & 3.8 \\
\hline 1895 & No.20Z & 54.7 & No.16S & 22.0 & No.15S & 5.7 \\
\hline 1896 & No.20Z & 35.6 & No.16S & 27.3 & No.14S & 10.8 \\
\hline 1897 & No.16S & 38.1 & No.20Z & 32.1 & No.15S & 11.0 \\
\hline 1898 & No.16S & 81.4 & No.10S & 5.9 & No.20Z & 4.0 \\
\hline 1899 & No.16S & 68.3 & No.14S & 8.4 & No.20Z & 7.2 \\
\hline 1900 & No.16S & 17.8 & No.14S & 12.1 & No.20Z & 12.0 \\
\hline 1901 & No.20Z & 27.9 & No.16S & 20.8 & No.12S & 8.8 \\
\hline 1902 & No.16S & 26.0 & No.14Z & 17.9 & No.13Z & 11.0 \\
\hline 1903 & No.16S & 29.0 & No. $14 Z$ & 11.4 & No.14S & 11.2 \\
\hline 1904 & No.16S & 31.0 & No.12S & 28.2 & No.12S & 22.0 \\
\hline 1905 & No.14S & 37.9 & No.16S & 30.2 & No.15S & 13.0 \\
\hline 1906 & No.14S & 37.0 & No.16S & 20.2 & No.12S & 7.5 \\
\hline 1907 & No.14S & 33.0 & No.20Z & 15.0 & No.16S & 15.0 \\
\hline 1908 & No.14S & 41.8 & No.20Z & 16.0 & No.16S & 10.4 \\
\hline 1909 & No.14S & 48.0 & No.20Z & 15.3 & No.16S & 9.4 \\
\hline 1910 & No.14S & 49.7 & No.20Z & 18.6 & No.13S & 7.8 \\
\hline 1911 & No.14S & 51.4 & No.20Z & 21.5 & No.16S & 6.3 \\
\hline 1912 & No.14S & 48.2 & No.20Z & 14.3 & No.12S & 8.1 \\
\hline 1913 & No.14Z & 35.0 & No.20Z & 21.8 & No.16S & 7.6 \\
\hline
\end{tabular}

Note: "S" and " $Z$ " after the figures which show the counts of yarn mean "Lefthand twist" and "Right-hand twist," respectively.

All production results are for December.

Sources: Dai Nippon Menshi Boseki Dogyo Rengo Kai Hokoku

Dai Nippon Menshi Boseki Dogyo Rengo Kai Geppo

Dai Nippon Boseki Rengo Kai Geppo

from the fact that Osaka Boseki's share in the production of all cotton yarn was only $8-9 \%$, it becomes clear how strongly Osaka Boseki was leaning towards production of no. 20 Z-twists. At the time, Settsu Boseki and Amagasaki Boseki were also putting efforts into the production of no. $20 \mathrm{Z}$-twists, and each made it the top of their line, but its ratio in their total output was between 25 and $28 \%,{ }^{15}$ and they did not concentrate on it to the extent that Osaka Boseki did. 


\section{Increases in the Export of Cotton Yarn}

With the rise in the proportion of no. 20 Z-twists in Osaka Boseki's output, naturally the proportion of thicker yarns of counts lower than 20 were reduced. No. $16 \mathrm{~S}$-twists, which were a major product among the thicker yarns, declined in output during the 1893-94 reconstruction after the fire, and even after the resumption of operation of the refurbished plant, their output did not rise substantially. As a result, Osaka Boseki's share of no. 16 counts fell to the $8 \%$ level in December of 1895, a level similar to or even below that of the Settsu, Hirano, Naniwa, Owari, Nagoya, Mie and Tokyo spinning mills. Although at this time there was an overall increase in the production of no. 20 counts in the Japanese spinning industry, the output of no. 16 S-twist remained highest among cotton yarns, and in 1894-95 comprised about $20 \%$ of total output. The shift in concentration of Osaka Boseki towards no. $20 \mathrm{Z}$-twists thus coincided with a withdrawal by the company from the largest cotton yarn market. But rather than a conscious withdrawal from the coarse yarn market by Osaka Boseki, this market shift suggests a situation in which the recovery of sales of heavy cotton yarns which had been lost after the fire of 1892 did not go as expected, and Osaka Boseki was suffering a gradual competitive decline in the sphere of sales of the thicker counts.

The vigorous export drive by Osaka Boseki in the latter half of the 1890 s can be seen to have been intimately linked to the constriction of its market for the lowest counts of cotton yarn as noted above. Its export sales began in 1889 , and in that year 50 bales $(20,000 \mathrm{lbs}$.) of cotton yarn ranging in counts from 12 to 22 were shipped to China, while in 1890 samples were sent to Shanghai and Korea. As well, in July of 1891 five bales (2000lbs.) of no. 20 Z-twists were exported to Amoy, and in 1893 one bale (400lbs.) each of nos. 12, 14 and 16 were sent to Shanghai in the hands of Handa Cotton Trading Company. After this period of trial sales, exports proceeded on a full scale from about 1894 , and the Business Report of Osaka Boseki reports:

Prospects for exports are promising.

We opened new markets in the Korean ports.

(First half of 1894)

(Latter half of 1894)

Exports to China have increased substantially every year.

(First half of 1896)

After the Sino-Japanese War (1894-95), as the center for expanding 
exports to China, the Yushin Yoko (Youxin Yanghang) Agency was set up in Shanghai.

Other companies proceeded to export their products, and Japan's export of cotton yarn, which had not been more than $420,000 \mathrm{lbs}$. in 1893 almost quadrupled each year until it was 56 million lbs. in 1896 and then rose to 136.5 million lbs. in $1899 .{ }^{16}$ This rapid growth in exports was facilitated by such systemic and external factors as the removal of the export duty on cotton yarn in July of 1894, the acquisition of special rights in China and Korea after the Sino-Japanese War, and the decline in exports to those two countries from Britain, America, India and others as a result of the rise in the exchange rate of gold-standard currencies against currencies of silver-standard countries, but pressure to export as the result of the slow-down in growth of the Japanese internal cotton yarn market was another factor. The output of textiles woven in Japan from cotton yarn increased substantially in the years after 1890, from 30,040,000 $\tan$ (bolts; $1 \tan =$ approx. 13 in. $\times 12$ yd.) in that year to $70,200,000 \tan$ in 1896 , but reaching a bottle-neck then and fluctuating around that level until about $1900 .{ }^{17}$ The fall-off in the growth of indigenous production of woven cotton goods struck a blow at the Japanese cotton spinning industry which provided its raw yarn, but it can be imagined that the blow was particularly severe for marginal suppliers. For enterprises which were weak in competition in the Japanese market, the opening of markets abroad became of crucial importance.

In the first half of 1897, the Osaka Cotton Spinning Company's exports of cotton yarn did not exceed 200-300 bales $(80,000$ $120,000 \mathrm{lbs}$.) per month, but during the year they increased so that by the end of 1897 exports to Shanghai reached 2,220 bales $(888,000 \mathrm{lbs}$.). These exports comprised as much as $80 \%$ of Osaka Boseki's average monthly output in that year. ${ }^{18}$ Subsequent fluctuations in the ratios of exports to Osaka Boseki's total output are as given in Figure 4, and it can be seen that the proportion of exports was particularly high between 1898 and 1900. In the composition of cotton yarn exports, no. 16 count yarn was most common, comprising $81-85 \%$ of exports in the years $1898-1900$. In relation to overall output, almost $60 \%$ of the output of no. 16 was exported. The second largest volume of exports were of no. 20 count, varying between $6 \%$ and $17 \%$ of all exports in those years. Thus, as the proportion of exports increased, with 1897 as a watershed, no. $16 \mathrm{~S}$-twists took over the largest share of the output of cotton yarn, and no. $20 \mathrm{Z}$-twists, which had been the most common yarn in the earlier half of the 1890 s, lost its preeminence (Table 2). No. 
Figure 4 Composition of Sales of Osaka Boseki's Cotton Yarn

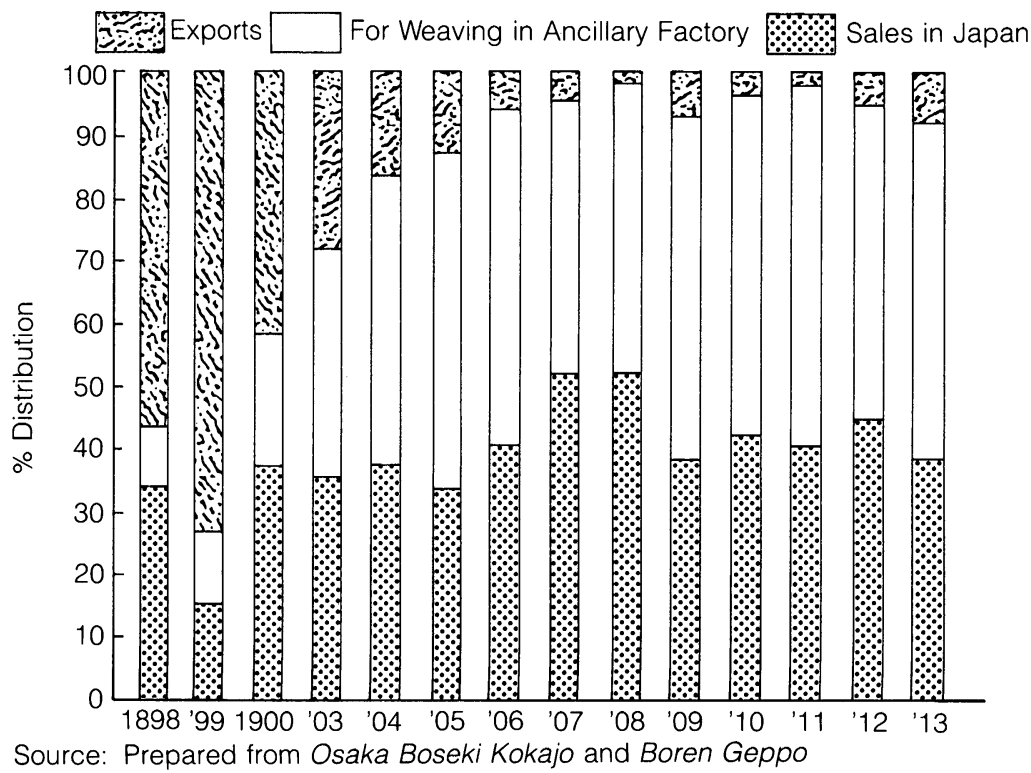

20 count cotton Z-twists, which had ousted Indian cotton yarn and led the way into the market for cotton yarn to make bleached cottons, as a result of the stagnation of indigenous cotton weaving and intensification of competition with the entry of other companies into the production of no. 20 yarns around 1897 (Osaka Boseki was losing its predominance in shares of no. $20 \mathrm{Z}$-twists in the market about this time), were no longer the basic product of Osaka Boseki. In their place, the Company was obliged to change its production and business plans to make no. $16 \mathrm{~S}$-twist which up to this time had not invariably sold well in Japan, the main focus of its export efforts.

Looking at the export ratios of other important cotton-spinning companies, in 1898 Kanegafuchi Cotton Spinning Company's 48.5\% and Settsu's $20.6 \%$ were high, while Amagasaki's $12.8 \%$ and Mie's $1.1 \%$ were lower. ${ }^{19}$ The fact that Osaka Boseki and Kanegafuchi Boseki, whose profitability in the latter half of the 1890 s was low, had high ratios of export to total production, while Mie Boseki and Amagasaki Boseki, whose profitability was high, had low export ratios, is worthy of note. Kanebo was second to Osaka Boseki in ratio of export to total production, but in its actual volume of exports it surpassed Osaka Boseki and took top place. And more than $80 \%$ of its 
Table 3 Changes in Supply and Demand of Cotton Yarn between 1889 and 1898: The Osaka Cotton Spinning Co. and Spinning Industry as a Whole

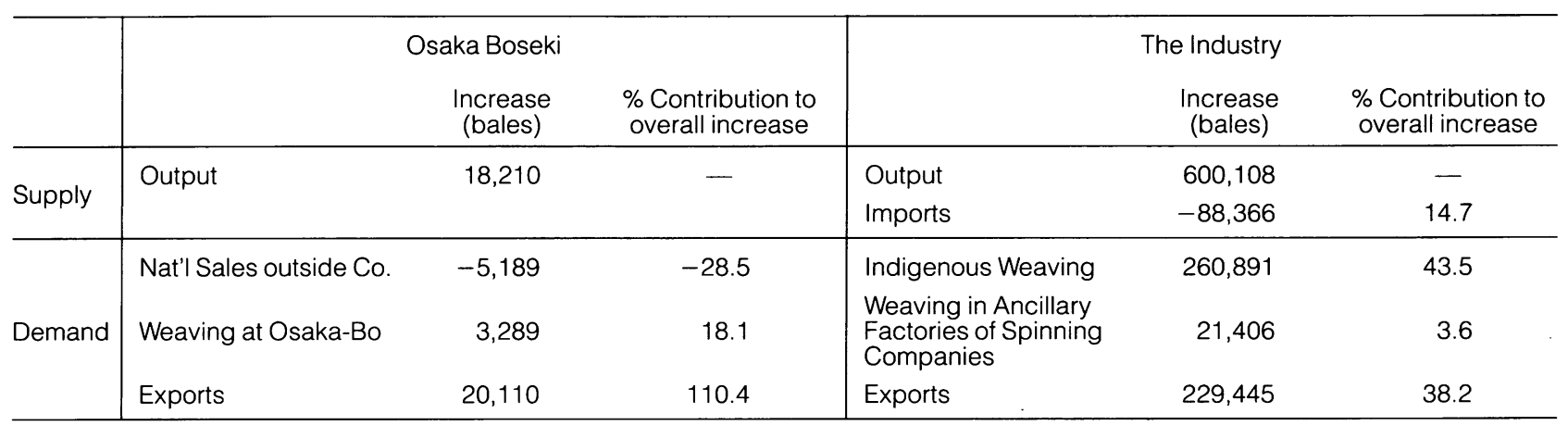

Sources: For Osaka Boseki, Kokajo (Business Reports) and Dai Nippon Menshi Boseki Rengokai Hokoku No.79 For the spinning industry, Takamura, Nihon Boseki-gyo shi Josetsu, Jo. pp. 146, 183, 223 and Hokoku No.79 
exports, like Osaka Boseki, were no. 16 counts. In the case of Settsu Boseki, whose profitability was high and export ratio relatively high, unlike Kanebo and Osaka Boseki the proportion of no. 20 cotton yarns in its exports was high. This was probably because it had secured a good market for no. 16s in Japan. In this way, at about the turn of the 19th century, substantial differences among the important spinning companies appeared in the export strategy. In contrast to Mie Boseki and Amagasaki Boseki (and perhaps we can include Settsu Boseki), successful in competition in the internal market but tending to concentrate their efforts at home, Osaka Boseki and Kanebo, which were weak in the internal competition but had invested heavily in plant, were obliged to put their expectations in external markets.

What significance did the increase in ratio of exports to total production have on Osaka Boseki's management? Let us add a few observations on this point below.

First, let us compare Osaka Boseki's reaction to changes in the pattern of demand for cotton yarn, which came about as the result of changes in the market, with that of the spinning industry as a whole. Table 3 has been prepared for this purpose, and it shows how, between 1889 when cotton yarn exports were negligible and ancillary weaving of spinning companies had not yet been started, and 1898 when exports were active and the ancillary weaving departments were getting on track, in relation to increases in Osaka Boseki's output of cotton yarn and the output and import of cotton yarn by the industry as a whole, the pattern of demand changed. What surprises us in looking at the table is that, although between 1889 and 1898 Osaka Boseki's output of cotton yarn increased by 18,210 bales (an increase of $106 \%$, with one bale weighing $400 \mathrm{lbs}$.), the amount sold within the country but outside the company was diminishing. Insofar as the comparison is between 1889 and 1898, Osaka Boseki could not cover the diminution of internal sales with the demand for yarn for weaving in its own factories, and the increase in output of cotton yarn depended largely on increased demand in external markets.

On the other hand, looking at the spinning industry as a whole, what contributed most to the increase in cotton yarn output in this period (an increase of $858 \%$ ) was a net increase in the volume used in indigenous cotton weaving industry. The contribution of expansion of external markets was also large, and import substitution cannot be ignored as a factor in expansion, but greater than these, the expansion of traditional cotton weaving production and the resultant increase in demand for raw yarn made the largest contribution to the growth of the 
Japanese spinning industry. At the time, the traditional small scale weavers were being modernized by introducing the drum machines and the batten machines, and was being reorganized and reinvigorated. Osaka Boseki's conspicuous reliance on foreign markets, when it might have taken advantage of the good conditions created by this development of the indigenous cotton weaving industry, can be thought to demonstrate the company's defeat in the competition among Japanese spinning companies in this period.

But again, if the sale of cotton yarn in foreign markets was more advantageous in terms of profits than its sale in Japan, Osaka Boseki's concentration on exports was not the passive response indicated above but could be considered an active strategy. So, secondly, let us examine this point. In February of 1898, the Shanghai price of Osaka Boseki's no. 16 count cotton yarn "Elephant" was 77.75 taels (of silver) per bale. ${ }^{20}$ At that time, as the exchange rate was 0.786 taels for one Japanese yen, ${ }^{21} 77.75$ taels was worth 98.92 yen. The wholesale price of one bale of no. 16 yarn in Osaka in February of 1898 was 92.5 yen. ${ }^{22}$ The Shanghai price was thus $6.9 \%$ higher than the Osaka wholesale price. Consequently, if the transport costs from Osaka via Kobe to Shanghai were less than $6.9 \%$ of the Shanghai price, marketing in Shanghai would be advantageous, but if it were more, selling it in Osaka would be more profitable. Transport costs for that period have not been examined, but according to the "Petition for Exemption from the Export Tariff on Cotton Yarn" presented to the Ministry of Agriculture and Commerce in January of 1893 by the Cotton Spinners' Association (Boren), ${ }^{23}$ the production cost of one bale of no. 20 yarn was 81.172 yen, the cost of exporting to Shanghai was 12.277 yen, and adding the two, the estimated price at Shanghai was 93.449 yen. In the production cost, however, the still extant import duty on raw cotton (1.4 yen), and in the exporting cost, the cotton yarn export duty (3.209 yen), were included, and since by 1898 both had been removed, if these are deducted, the Shanghai price would have been 88.84 yen and an exporting cost of 9.068 yen would amount to $10.2 \%$ of the Shanghai sale price. So, if we assume an exporting cost of about $10 \%$, in order to sell one bale at Shanghai in February of 1898 for 77.75 taels (98.92 yen), the shipping price at Osaka would have had to be 89 yen, or 3.5 yen lower than the Osaka wholesale price at the time.

From the above considerations, it can probably be said that in order for Osaka Boseki to market its products more profitably at Shanghai than at Osaka, great efforts were needed. For those spinning companies which had assured markets in Japan, there was probably no 
strong incentive to devote their efforts to exporting.

\section{Osaka Boseki's Strategies to Strengthen the Weaving Department}

The Japanese cotton spinning industry, which had grown rapidly in the $1890 \mathrm{~s}$, met a major obstacle as it entered the 20th century. In the recession which began about 1897 , exports turned favorable between 1897 and 1899 and output even increased slightly, but the price of cotton yarn dropped substantially. Then in the years 1900-1901 the depression set in in earnest, and even though the price of cotton yarn recovered, output and sales plummeted. The current Business Report of Osaka Boseki reported that the company's cotton yarn division was facing its greatest predicament since its establishment.

The appearance of market conditions different from those of the 1890 s obliged cotton spinning companies to adopt new business strategies. The main strategical choices were essentially as follows. One was to amalgamate the medium and small spinning companies which had suffered business difficulties in the depression, and thus to seek economies of scale in production, marketing and financing. In the field of thicker yarns for export where it was necessary to produce and sell cheap goods in large quantities, this strategy was essential. Kanegafuchi Boseki and Osaka Godo Boseki, as well as Settu Boseki, adopted this strategy and pursued take-overs. The absorption by Kanegafuchi of Shanghai Boseki and Kyushu Boseki, by Settsu of Hirano Boseki and by Osaka Godo of Tenma Boseki, the latter ${ }^{\prime}$ 'll companies which had high proportions of exports, became the meats of raising the proportion of exports of the three companies taking them over. As we have seen above, in 1898 Kanegafuchi's ratio of exports was $48.5 \%$ and Settsu's was $20.6 \%$, and even with the rise in the exchange rate vis-à-vis China at the beginning of the 20th century, exports were maintained, so that in 1903 Kanegafuchi's exports at $53.4 \%$ of production, and Settsu Boseki's, at $58.4 \%$, had not only risen but were to remain at a high level in the first decade of the $1900 \mathrm{~s} .{ }^{24}$

The second strategy was, while winking at the internal market for thicker yarns from which foreign yarns had already been ousted, to move actively into the market for medium and higher counts of fine yarn which was still monopolized by imported yarn. At a time when an increased demand for higher-class cotton cloth in Japan was foreseen, this was also an advantageous strategy. Concretely, the production of nos. 32 and 42 doubling yarns used in two-ply weaves, cotton flannel and cotton tweed (kokura), etc., was emphasized by Amagasaki 
Figure 5 Composition of Osaka Boseki's Sales

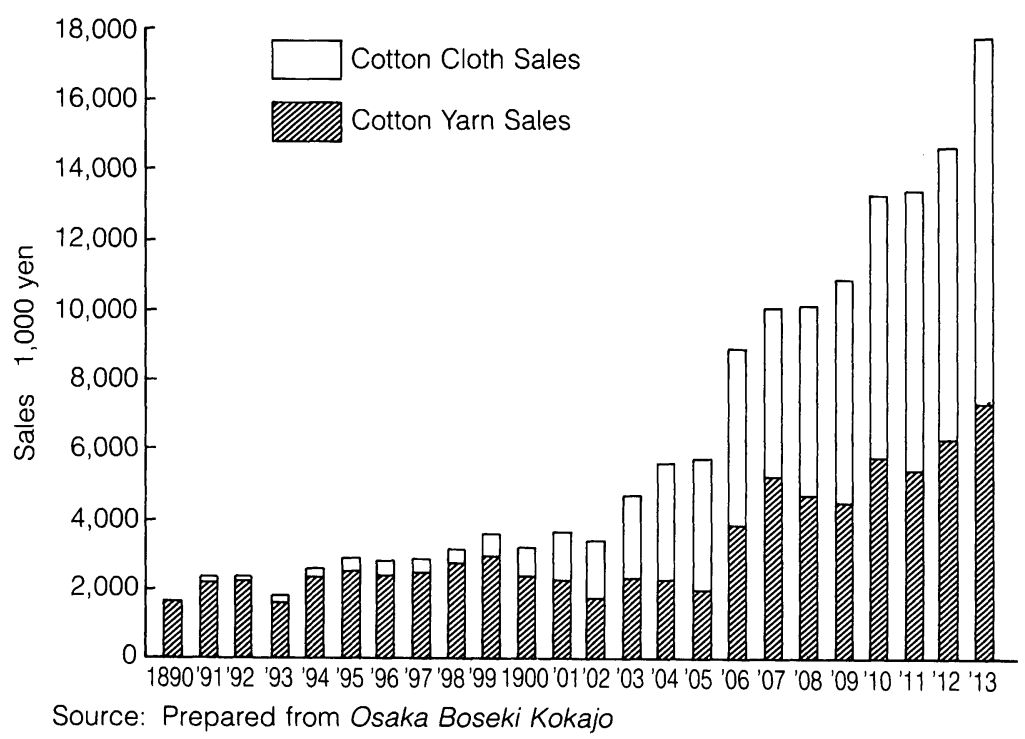

Boseki and Osaka Godo Boseki, while that of nos. 60 and 80 gassed yarn used in kurume, tie-dyed fabric (kasuri), mino striped, gassed two-ply weaves and other weaves, was developed by Tokyo Gassed Yarn and Nippon Spinning.

The third strategy, in a situation in which the export of cotton yarn and the market for yarns used in traditional cotton weaving were both stagnant but the demand for cotton cloth for export was good, was to strengthen ancillary weaving and find new outlets for the export of woven cottons. Osaka Boseki, which had started ancillary weaving early on and turned its hand to the development of the export market, along with Mie Boseki adopted this third strategy. As mentioned above, the Osaka Spinning Co. undertook no expansion of its spinning plant between 1895 and 1905, but in that period increased its weaving frames from 579 to 1,754 looms, and particularly after 1901 expanded its weaving plant at a fast pitch.

By adopting the policy of strengthening its weaving sector, Osaka Boseki changed its commodity and marketing structure considerably. As can be seen in Figure 5, from about 1900 into 1905, sales of cotton yarn outside the company showed a tendency to decrease, but sales of cotton cloth rose steadily, surpassing $50 \%$ of all sales for the first time in 1906 and reaching almost $60 \%$ thereafter. In the make-up of its mar- 
ket for cotton yarn, the export ratio declined rapidly after 1900 , and in place of exports, the ratio of yarn used in the ancillary weaving factories increased conspicuously (Figure 4). Correspondingly, the ratio of no. $16 \mathrm{~S}$-twists, previously the major export commodity, in total production dropped, while the proportion of thicker counts from nos. 12 to 14 used in Osaka Boseki's major woven products like T-cloth (tenjiku-fu), sheeting (sofu) and cotton drill (aya-momen) rose. The average count in the production of the spinning industry as a whole was gradually rising, but Osaka Boseki was going in a direction opposite to this trend.

In this way, after the early 1900s Osaka Boseki, rather than as a specialized cotton spinning company, was strengthening its position as what should be called a spinning and weaving company. And as has been noted above, this was indeed one of the strategic options open to leading spinning companies of the time. But why, among the three strategic options outlined above, did the Osaka Cotton Spinning Company choose the third, the strategy of developing its weaving sector? Participation in the production of medium and higher counts of cotton yarn (the second strategy) was not an area in which Osaka Boseki had had experience, and even though it might have been expected to do well, because at the time the scope of the market was still limited the company did not choose this strategy (Osaka Boseki actually installed ring doubler machines between 1902 and 1904 but the production of doubling yarns was not expanded thereafter). But if we agree that this was so, we must still ask why the company which in the latter half of the 1890 s had one of the highest ratios of exports among spinning companies and controlled a large share of the export market did not, like Kanegafuchi Boseki and Settsu Boseki, choose the strategy of expanding its plant for the production of thicker yarns for export.

It might be thought that the reason was a shortage of funds to invest in plant or with which to buy up other enterprises. At the time, however, Osaka Boseki was investing funds in weaving plant expansion, and therefore the financial situation cannot have been decisive. A more important reason was probably that Osaka Boseki's cotton yarn had lost its competitive edge in foreign markets. The Shanghai price for Japanese no. 16 cotton yarns in February of 1898 was 77.75 taels for one bale of Osaka Boseki's product (used above), 77.50 taels for Hirano's, 77.25 for Settsu's and Kanegafuchi's, and 77 taels for that of Tenma Boseki and others, so that Osaka Boseki's price was slightly higher. It can be supposed that, to this extent, Osaka Boseki's cotton 
yarn was more highly valued at Shanghai than that of other Japanese spinning companies. On the other hand, according to similar data for June of 1902, while Osaka Boseki's product sold for 87.25 taels, Kanegafuchi's at 92.25 taels and those of Hirano and Kurashiki at 88 taels had replaced it, compared to many other spinning companies' cotton yarn, it had become cheaper. ${ }^{25}$

Changes after 1904 are shown in Table 4, and the price of Osaka Boseki's cotton yarn had clearly dropped below those of Kanegafuchi Boseki and Settsu Boseki, to the level of Kurashiki Boseki. This can be assumed to show that the quality of Osaka Boseki's cotton yarn had come to be regarded as lower than that of Kanegafuchi Boseki and Settsu Boseki. In fact, Kanegafuchi and Settsu in the early 1900s concentrated on producing high quality coarse yarns from good quality cotton fibers and were said to be developing these as weapons in an export offensive. ${ }^{26}$ Its tardiness in this qualitative competition brought about Osaka Boseki's decline in exports.

Let us further examine the profitability of Osaka Boseki's exports of cotton yarn in the latter half of the first decade of this century. As well as the Shanghai price of each spinning company's cotton yarn, in Table 4 the Osaka wholesale prices of no. 16 yarn (brands unidentified) are given. From 1904 to the early part of 1907, the price of cotton yarn in Japan showed a consistent rise, but because of the tendency of the exchange rate of yen in relation to taels of Chinese silver to drop, the export price was stabilized and the export of Japanese yarn which had been at the $70-80$ million $\mathrm{lb}$. level between 1900 and 1902 rose to more than 100 million lbs. in the period $1903-06 .{ }^{27}$ Comparing the price of Japanese cotton yarn in Shanghai with the Osaka wholesale price (in taels) in order to estimate the profitability of exports in this period, as can be seen from Table 4, while the Shanghai price of Kanegafuchi Boseki's yarn was $6-9 \%$ higher than the Osaka wholesale price and Settsu Boseki's 5\% higher, in the cases of Osaka Boseki and Kurashiki Boseki, the Shanghai price was only $1-2 \%$ higher. In this calculation, if we consider export costs, we cannot avoid doubt about the profitability of the cotton yarn exports of even Kanegafuchi and Settsu, but even more in the case of Osaka Boseki, its exports of cotton yarn to Shanghai, rather than an attempt to garner profits, can be assumed to have been aimed solely at maintaining the scale of its operations and thereby reducing the unit costs at its products. In this sense, Osaka Boseki's strategy of strengthening its weaving sector was a change to a reactive strategy prompted by its poor showing in competition in foreign markets. 
Table 4 Shanghai Prices and Osaka Wholesale Prices of Various Companies' No.16 Cotton Yarn

\begin{tabular}{|c|c|c|c|c|c|c|c|c|c|c|c|}
\hline & $\begin{array}{c}\text { Osaka } \\
\text { Boseki } \\
\text { tael/bale } \\
\text { (A) }\end{array}$ & $\begin{array}{l}\text { Shangha } \\
\text { Kanegafuchi } \\
\text { Boseki } \\
\text { tael/bale } \\
\text { (B) }\end{array}$ & $\begin{array}{l}\text { Prices } \\
\text { Settsu } \\
\text { Boseki } \\
\text { tael/bale } \\
\text { (C) }\end{array}$ & $\begin{array}{l}\text { Kurashiki } \\
\text { Boseki } \\
\text { tael/bale } \\
\text { (D) }\end{array}$ & $\begin{array}{c}\text { Japanes } \\
\text { Osaka Who } \\
\text { yen/bale } \\
(E)\end{array}$ & $\begin{array}{l}\text { Pe Price } \\
\text { taesale Price } \\
\text { t(F) }\end{array}$ & $\begin{array}{c}\text { Exchange } \\
\text { Rate } \\
\text { (Shanghai) } \\
\text { tael/100 yen }\end{array}$ & $\begin{array}{c}A / F \\
\%\end{array}$ & $\begin{array}{c}B / F \\
\%\end{array}$ & $\begin{array}{c}\mathrm{C} / \mathrm{F} \\
\%\end{array}$ & $\begin{array}{l}D / F \\
\%\end{array}$ \\
\hline 1904 First Half & 91.75 & 94.25 & 94.25 & 92.50 & 116.65 & 91.97 & 78.84 & 99.8 & 102.5 & 101.1 & 100.6 \\
\hline Second Half & 93.75 & 98.50 & 95.38 & 94.00 & 116.15 & 89.98 & 77.47 & 104.2 & 109.5 & 106.0 & 104.5 \\
\hline 1905 First Half & 95.00 & 102.25 & 97.75 & 95.25 & 123.35 & 93.09 & 75.47 & 102.1 & 109.8 & 105.0 & 102.3 \\
\hline Second Half & 95.25 & 99.75 & 98.00 & 95.13 & 127.80 & 93.49 & 73.16 & 101.9 & 106.7 & 104.8 & 101.8 \\
\hline 1906 First Half & 93.50 & 98.00 & 94.88 & 93.25 & 130.00 & 90.73 & 69.79 & 103.1 & 108.0 & 104.6 & 102.8 \\
\hline Second Half & 89.88 & 92.75 & 91.75 & 89.00 & 130.30 & 87.48 & 67.14 & 102.7 & 106.0 & 104.9 & 101.7 \\
\hline 1907 First Half & 91.38 & 92.00 & 92.00 & 89.75 & 131.80 & 90.32 & 68.53 & 101.1 & 101.9 & 101.9 & 99.4 \\
\hline Second Half & 90.00 & 91.25 & 90.75 & 89.75 & 119.65 & 87.70 & 73.30 & 102.6 & 104.0 & 103.5 & 102.3 \\
\hline 1908 First Half & 91.50 & 93.00 & 93.00 & 91.25 & 108.00 & 89.74 & 82.49 & 102.0 & 103.6 & 103.6 & 101.7 \\
\hline Second Half & 95.73 & 97.00 & 96.00 & 95.25 & 109.20 & 95.54 & 87.49 & 100.2 & 101.5 & 100.5 & 99.7 \\
\hline 1909 First Half & 103.75 & 105.50 & 104.13 & 104.00 & 116.30 & 100.70 & 86.34 & 103.0 & 104.8 & 103.4 & 103.3 \\
\hline Second Half & 109.00 & 110.88 & 110.50 & 110.25 & 124.55 & 107.97 & 86.69 & 101.0 & 102.7 & 100.8 & 102.1 \\
\hline 1910 First Half & 117.00 & 115.13 & 114.75 & 115.75 & 131.55 & 111.99 & 85.26 & 104.5 & 102.8 & 104.8 & 104.9 \\
\hline Second Half & 115.00 & 117.50 & 117.38 & 117.50 & 136.65 & 112.53 & 82.35 & 102.2 & 104.4 & 104.3 & 104.4 \\
\hline 1911 First Half & 125.38 & 128.00 & 127.63 & 127.63 & 152.45 & 127.27 & 83.49 & 98.5 & 100.6 & 100.3 & 100.3 \\
\hline
\end{tabular}

Sources: For Shanghai Prices, Menshi boseki Jijo Sanko-sho

For Osaka Wholesale Prices, Meiji-ki Osaka oroshi-uri bukka shiryo 7, Osaka Daigaku Keizai Gaku, vol.31 no.4 For Exchange Rates, Asahi Shimbun, ed., Nihon Keizai Tokei Sokan, 1930 


\section{Development of the Weaving Department of the Osaka Cotton Spinning Company}

In this way, after the early 1900 s, the weaving department became the leading operational unit of Osaka Boseki. Below, we will look at its development.

The absorption of the Osaka Weaving Cloth Company (Osaka Shokufu Kaisha) in 1890 provided the opportunity for the start of ancillary weaving at Osaka Boseki. Osaka Weaving Cloth Company had been established in 1887 by nine people, including Takeo Yamanobe, Jutaro Matsumoto, Tatsutaro Kumagai, Seiichiro Saeki, Seizo Kamata and Shinzaburo Akima, all shareholders in Osaka Boseki, and thus had in effect the character of another division of Osaka Boseki. Beginning production in 1889, it turned out T-cloth (tenjiku-fu), cotton coating (kokura-ori), table cloths and so on, but it was not so profitable. That was because, although it tried to produce many varieties in small quantities like the traditional weavers who had gone so far as to mix several varieties of cloth in one bale, the Osaka Weaving Cloth Company could not compete with the hand weavers in cost and was inefficient in weaving and dyeing when filling small orders. ${ }^{28}$ Hence, when with the influence of the 1890 depression the independent management of Osaka Weaving Cloth became difficult, it was taken over by Osaka Boseki in October of that year.

The business state of the weaving plant, which became the Matsushima factory of Osaka Boseki, was not very favorable at first. Concerning the situation, the Abridged History of the First 25 Years of Osaka Boseki says that "The prospects for the cotton weaving industry are good, but after about the beginning of 1902 there were many producers of similar cloth in the Kinai region (around Osaka) and the competition is rather intense, $" 29$ suggesting that Osaka Boseki's cotton cloth was not fully competitive. Generally speaking, at this time the situation was such that mechanically-woven cotton cloth "did not fully demonstrate the capabilities of machines because it was woven from cotton yarn the quality of which was not even." 30 Cotton yarn used in the Weaving Division currently did not exceed 6-9\% of Osaka Boseki's yarn output. Rather than an income-making sector, the Weaving Division can be considered to have been acting as a regulator of supply and demand for the company's cotton yarn.

The Weaving Division took the opportunity of the Sino-Japanese War to make a great leap forward. This was possible because of the large demand for cloth for military uniforms. The cloths used in 
Table 5 Composition of Osaka Boseki's Cotton Weaving Product

\begin{tabular}{|c|c|c|c|c|c|c|c|c|c|c|c|c|c|c|}
\hline & \multicolumn{2}{|c|}{$\begin{array}{c}\text { T-Cloth } \\
\text { (Tenjiku-fu) }\end{array}$} & \multicolumn{2}{|c|}{$\begin{array}{l}\text { Sheeting } \\
\text { (Sofu) }\end{array}$} & \multicolumn{2}{|c|}{$\begin{array}{l}\text { Shirting } \\
\text { (Kanakin) }\end{array}$} & \multicolumn{2}{|c|}{$\begin{array}{c}\text { Cotton Drill } \\
\text { (Aya-Momen) }\end{array}$} & \multicolumn{2}{|c|}{$\begin{array}{l}\text { Unsai (Cotton } \\
\text { Drill for Military) }\end{array}$} & \multicolumn{2}{|c|}{ Flannel } & \multicolumn{2}{|c|}{$\begin{array}{c}\text { Duck } \\
\text { (Atsuori-Momen) }\end{array}$} \\
\hline & $\begin{array}{l}\% \text { of } \\
\text { Output } 1\end{array}$ & $\begin{array}{c}(\% \text { of } \\
\text { Nat'l total) }\end{array}$ & $\begin{array}{l}\% \text { of } \\
\text { Output }\end{array}$ & $\begin{array}{c}\text { (\% of } \\
\text { Nat'l total) }\end{array}$ & $\begin{array}{l}\% \text { of } \\
\text { Output }\end{array}$ & $\begin{array}{l}(\% \text { of } \\
\text { Nat'l total) }\end{array}$ & $\begin{array}{l}\% \text { of } \\
\text { Output }\end{array}$ & $\begin{array}{l}\text { (\% of } \\
\text { Nat'l total) }\end{array}$ & $\begin{array}{l}\% \text { of } \\
\text { Output }\end{array}$ & $\begin{array}{c}\text { (\% of } \\
\text { Nat'l total) }\end{array}$ & $\begin{array}{l}\% \text { of } \\
\text { Output }\end{array}$ & $\begin{array}{c}\text { (\% of } \\
\text { Nat'l total) }\end{array}$ & $\begin{array}{c}\% \text { of } \\
\text { Output }\end{array}$ & $\begin{array}{c}(\% \text { of } \\
\text { Nat'l total) }\end{array}$ \\
\hline 1896 & 25.6 & (13.7) & 0.1 & (100.0) & 0.5 & $(0.3)$ & 14.0 & (99.1) & 9.8 & $(100.0)$ & 5.8 & (20.5) & 35.4 & (82.5) \\
\hline 1898 & 47.1 & $(13.2)$ & - & $(-)$ & - & $(-)$ & 16.6 & $(100.0)$ & - & $(-)$ & 6.5 & $(58.0)$ & 28.0 & $(100.0)$ \\
\hline 1899 & 57.6 & (25.7) & 1.5 & $(76.7)$ & 0.3 & $(0.2)$ & 10.8 & $(100.0)$ & 20.2 & (55.0) & - & $(-)$ & 3.4 & $(42.7)$ \\
\hline 1900 & 62.8 & $(29.8)$ & - & $(-)$ & 3.2 & (2.6) & 6.1 & $(78.3)$ & 14.8 & $(43.0)$ & - & $(-)$ & - & $(-)$ \\
\hline 1901 & 50.5 & $(41.0)$ & 12.8 & $(100.0)$ & 24.2 & $(21.5)$ & 2.7 & $(32.8)$ & 6.6 & (45.1) & 1.4 & (3.9) & 0.7 & $(19.4)$ \\
\hline 1902 & 48.5 & $(40.4)$ & 29.5 & (83.3) & 16.6 & $(28.0)$ & 4.5 & $(80.1)$ & - & $(-)$ & 0.6 & (8.3) & 0.3 & $(21.0)$ \\
\hline 1904 & 3.4 & (5.3) & 24.6 & (22.4) & 1.5 & (5.2) & 11.0 & (34.9) & 28.4 & (43.3) & - & $(-)$ & 30.9 & $(47.4)$ \\
\hline 1905 & 11.5 & $(16.1)$ & 37.4 & (26.0) & 2.7 & (12.5) & 8.8 & (29.5) & 19.6 & $(50.0)$ & - & $(-)$ & 19.6 & (39.8) \\
\hline 1906 & 19.6 & $(21.9)$ & 48.6 & $(36.2)$ & 2.7 & (13.7) & 20.6 & (53.3) & 3.5 & $(52.7)$ & 1.4 & (2.1) & 3.4 & (32.3) \\
\hline 1907 & 9.8 & (19.1) & 41.7 & $(36.9)$ & 3.9 & $(23.0)$ & 27.8 & $(52.7)$ & 2.9 & (38.9) & 12.2 & (3.8) & 1.8 & (19.7) \\
\hline 1908 & 6.2 & (13.5) & 43.8 & $(36.7)$ & 1.1 & (5.6) & 33.1 & $(58.7)$ & 1.7 & $(30.7)$ & 11.8 & $(19.4)$ & 2.2 & (23.5) \\
\hline 1909 & 6.3 & (14.5) & 35.5 & (32.3) & - & $(-)$ & 30.3 & $(46.3)$ & 0.4 & (21.7) & 27.4 & (34.8) & - & $(-)$ \\
\hline 1910 & 1.9 & (5.5) & 38.3 & (26.3) & 0.3 & $(0.1)$ & 47.0 & $(58.6)$ & 0.1 & (22.9) & 12.0 & (20.5) & - & $(-)$ \\
\hline 1911 & 2.9 & (7.4) & 46.6 & (27.1) & 6.2 & (12.9) & 30.0 & $(47.1)$ & - & $(-)$ & 14.1 & (26.5) & 0.2 & $(4.2)$ \\
\hline 1912 & 5.4 & (14.8) & 36.1 & (18.2) & 28.1 & $(27.4)$ & 17.6 & $(37.0)$ & - & $(-)$ & 12.1 & (23.9) & 0.1 & (1.0) \\
\hline 1913 & 3.4 & $(11.8)$ & 29.3 & (17.9) & 20.5 & (18.4) & 39.7 & $(41.9)$ & - & $(-)$ & 7.1 & (14.5) & - & $(-)$ \\
\hline
\end{tabular}

Source: Dai Nippon Boseki Dogyo Rengo Kai Hokoku and Menshi Boseki Jijo Sanko-sho

$\pm \quad$ For 1904, figures are for the latter halves of years. 
Table 6 Exports of Osaka Boseki's Cotton Cloth

\begin{tabular}{rrrrrr}
\hline & $\begin{array}{c}\text { China } \\
(1,000 \text { yds. })\end{array}$ & $\begin{array}{c}\text { Korea } \\
(1,000 \text { yds. })\end{array}$ & $\begin{array}{c}\text { Quantity } \\
(1,000 \text { yds. })\end{array}$ & $\begin{array}{c}\text { Value } \\
(1,000 \text { yds. })\end{array}$ & $\begin{array}{c}\text { Po.'s Cloth Output } \\
\text { Corcentage of }\end{array}$ \\
\hline 1897 & 857 & 220 & 1,076 & 362 & 32.5 \\
1898 & 1,268 & 379 & 1,647 & 408 & 37.7 \\
1899 & 1,893 & 562 & 2,455 & 540 & 37.7 \\
1900 & 1,809 & 637 & 2,466 & 816 & 26.9 \\
1901 & 2,017 & 1,237 & 3,255 & 1,339 & 21.3 \\
1902 & 10,056 & 860 & 10,915 & 2,041 & 42.3 \\
\hline
\end{tabular}

Source: Teiji Yamauchi, Osaka ni okeru yushutsu kikai menpu chosa hokoku in Dai Nippon Boseki Rengo Kai Geppo, no. 160

uniforms were cotton coating (kokura), duck (atsuori-momen), unsai drill and so on. Duck (atsuori-momen) was thick, flat-woven cloth using both warps and wefts of about no. 16 yarn, and of 31 ins. in width, 24-40 yds. long, and weighing about 9-15lbs. Unsai was a thick kind of cotton drill, using single yarns for warps and wefts of nos. 14-20, 30 ins. wide, 40 yds. long, and weighing about $13-14 \mathrm{lbs}$. Woven in twill construction, for uniforms cotton warps and wefts of about no. 12 were used. ${ }^{31}$ In the latter half of the 1890 s the proportion of material for uniforms was high, and in 1896 production, duck was first and unsai second, taking up $42.5 \%$ of output. And in this field, Osaka Boseki had a virtual monopoly as a supplier (Table 5).

Another major woven product at the time was T-cloth (tenjiku-fu). Tenjiku-fu, or T-cloth, taking its name from the fact that it was originally imported from India (known in ancient times as tenjiku), used warps and wefts from no. 16 to no. 24 , with no. 20 most common, and had a width of 30 ins., a length of 24 yds., and weighed $15-16 \mathrm{lbs} .^{32}$ It was said to be easier to weave than shirting and was the cloth which originally displaced imports, but by the latter half of the 1890 s it had become a major cotton cloth export, and in 1898 exports exceeded imports. Osaka Boseki had started to export cotton cloth to China in 1893, and in the latter part of 1894 began its export to Korea as well. Thus by 1897 , Osaka Boseki's exports of cotton cloth reached $32.5 \%$ of its total production (Table 6).

As we have seen above, in the 1890s not only Osaka Boseki but mechanized weaving companies generally were largely dependent on military demand and foreign markets. Mechanized weaving companies, in responding to the traditional pattern of consumption in the internal mass market, found that the production of many varieties in 
small lots was inappropriate and that they did not have adequate resources to compete with the indigenous hand weavers in that way, but they could produce military uniform cloth and plain greys for export, cotton cloths which were woven in limited varieties in large lots. At the time, Osaka Boseki's dependence on military orders was relatively heavy, while the Kanakin Cotton Cloth Company concentrated on exports. Neither could rely on the internal market, and they shared a precarious dependence on unstable demand.

As we have seen, in the early years of the 20th century, Osaka Boseki had dug itself into weaving more and more deeply and increased its exports of woven cloth. In the latter part of 1889, it undertook a 120-loom expansion, in 1900 Takeo Yamanobe went to America and bought 500 "new-type power looms" (Northrop automatic power looms), and in 1901 a new weaving plant was installed in the Sangenya factory. As a result, Osaka Boseki's cotton cloth output increased by leaps and bounds after 1901 (Figure 5).

There were significant changes in product and market patterns of Osaka Boseki in the first decade of this century. The weight of cotton cloth for military purposes, such as duck (atsuori-momen) and unsai, became less after about 1900, and in their place, products such as Tcloth (tenjiku-fu), sheeting (sofu), shirting (kanakin) and cotton drill (aya momen) became the main products (Table 5). In sales outlets, foreign markets became ever more important. In China, about 1900 a representative was sent to Tianjin (Tientsin) and an agency for sales of both indigenous and Japanese cotton was established, showing that the China market was of great importance to Osaka Boseki. Table 6 shows that in 1902, of Osaka Boseki's output of cotton cloth, $42.3 \%$ was exported, while $39.0 \%$ of output was destined for China.

The basic exports were T-cloth (tenjiku-fu) and sheeting (sofu). In China, T-cloth (tenjiku-fu) was used widely for linings of clothing and bed-cloths, and its import reached substantial proportions, and particularly in northern China, Japanese T-cloth was popular. Among shippers, Osaka Boseki took the lead in exports to China, and $66 \%$ of its output of T-cloth was sent to China in 1902. A representative brand was Kingyo (Goldfish), the warps and wefts of which were both no. 20 count. ${ }^{33}$ It is said that sofu (sheeting) was the original name for Japanese shirting (kanakin). That is, in contrast to the common original English "shirting", fine cloth woven flat from warps of nos. 28-36 and wefts of nos. 30-54 cotton yarn; in Japan, where medium fine yarns were not being produced, it was only woven from warps and wefts of nos. 14-15 yarn, and although it was called "kanakin," it was thick 
cloth of poor quality. In other countries it soon became known as "sofu" (literally "rough cloth") ${ }^{34}$ In northern China, local cotton cloth made in the country was used, but at the beginning of the 20th century, sheeting (sofu) was imported in large quantities from America and took over the market. In competition, Japanese sofu took advantage of the sharp rise in American raw cotton which made American sheeting expensive, and after the middle of 1897 began to flow into China and establish itself in the North China market. ${ }^{35}$ Osaka Boseki led this drive, and in 1902 exported $88 \%$ of its output of sofu (mainly to China and Korea). Typical brands were "Marutor" (Winging Bird) and "Wash" (Eagle), and all were made with no. 14 warps and no. 13 wefts, were 36 in. by 40 yds., and were heavy cloths weighing 1315lbs. ${ }^{36}$ Thus in 1902 the Osaka Cotton Spinning Company monopolized $48.4 \%$ of cotton cloth exports from Japan to China.

In the first decade of this century, by expanding its weaving plant and putting efforts into developing export markets for cotton cloth, the weaving division of Osaka Boseki was making great strides to overcome the stagnation of the spinning division. While the Business Report of Osaka Boseki for the 1900s complains of the poor condition of cotton yarn sales, it also records the active nature of cotton cloth exports.

It is true that from the latter part of 1902 until immediately after the outbreak of the Russo-Japanese War at the beginning of 1904 exports were sluggish, but military demand made up for this hiatus. In 1904-05, production of unsai and duck for military uniforms increased dramatically while output of T-cloth for export decreased. In the 1904 Business Report, it was reported that, "With the progress of the War, military demand is increasing." Obliged to respond to this demand, the company expanded its weaving plant and increased the number of its looms.

The military requirements, however, were temporary, and after the end of the War renewed efforts were necessary to increase exports. Such efforts were devoted to entry into the Korean market which until now had been more or less cornered by the Kanakin Cotton Cloth Company. In 1904, a representative was sent to Inchon and five Japanese cotton merchants in Seoul and Inchon were organized as a cotton cloth sales association called the Kyoseisha and began licensed sales. After that, other companies also attempted exports to Korea and competition among Japanese spinning companies in the Korean market became fierce, but particularly intense was the competition between three, the Osaka Cotton Spinning Company, the Kanakin 
Cotton Cloth Company, and the Mie Cotton Spinning Company. To control this competition, with the assistance of the Mitsui Trading Company (Mitsui Bussan) the well-known San'ei Kumiai (Three Prosperities Association) was formed in 1906.

As a result of the establishment of the San'ei Kumiai, exports of Japanese cotton cloth to Korea increased conspicuously. In 1905, in exports to Korea, England was on top with Japan exporting about half as much, but in 1907, compared to England's 430,000 bolts, Japan topped that with 460,000 , and subsequently Japan increased its advantage every year. The export share of the San'ei Kumiai was large, reaching $70-90 \%$ of exports to Korea by about 1909 . After 1907 , other companies also established licensed dealers and attempted to increase their exports to Korea, but they could not penetrate the fortress of the San'ei Kumiai, and the Korean market for grey sheeting became the preserve of the San'ei Kumiai. ${ }^{37}$ By agreement under the San'ei Kumiai, the three companies' shares of exports were four for Osaka Boseki, three for Mie Boseki and three for Kanakin, with Osaka Boseki's trademark used in common by all three, so that it had a somewhat stronger position in the association. The export of cotton cloth to Korea seems to have been a big money-winner for Osaka Boseki, and one of its staff at the time said that "Even in difficult times, Daibo (Osaka Boseki) made profits in Korea, and as a result found the going relatively easy." 38

In the Chinese market, with the purpose of promoting exports to northern China and the north-eastern region (Manchuria), the Japan Cotton Cloth Export Association was formed in February of 1908 by five companies, Osaka Boseki, Mie Boseki, Okayama Boseki, Kanakin and Tenma Weaving, under the leadership of Mitsui Bussan. ${ }^{39}$ This Export Association had as its goal the securing of the Manchurian market which was dominated by American sheeting. And, "resolving to take on the Americans, the Export Association began sales at a price one tael less than the 6 taels or so per bolt of American sheeting," 40 thus engaging in price-fixing with American sheeting in mind. In this regard, the American Government protested to the Japanese Government, promoted a campaign to censure Japan's export offensive and tried to deal with Japanese products by means such as lowering the price of American cotton cloth. And in China, the boycott movement got underway. As a result of this international pressure and low prices, the export accounts of the Cotton Cloth Export Association were not invariably satisfactory. The state of affairs was such that, according to the Business Reports, 
Exports to Manchuria are not profitable.

(First half of 1907)

Although we are making our prices the same as those of American cotton cloth, as a result of the fall in the exchange rate for silver, profits are not forthcoming.

(Latter half of 1907)

As we have formidable rivals in American products, sales prices are moderate and profits modest.

(First Half of 1910)

In this way, although the Japan Cotton Cloth Export Association endeavor required not a few sacrifices from the member companies and Mitsui Bussan, in the matter of securing the Manchurian market its results were remarkable. In imports of grey cotton fabrics to Manchuria, Japan's share did not exceed $0.3 \%$ in 1904 and $2 \%$ in 1905, but in 1906 suddenly jumped to $30 \%$, by 1910 had reached $65 \%$, and in 1911 was up to $72 \%$. In these exports of Japanese cottons to Manchuria, moreover, $99 \%$ in 1906 and $76 \%$ in 1910 were handled by the Japan Cotton Cloth Export Association. ${ }^{41}$ Thus, as the Business Report for the latter half of 1910 says, "Sales spread from southern to northern Manchuria and regions like that of Harbin have become good prospective markets." The proportion of exports to Manchuria through the Export Association gradually decreased after this, and in June of 1912 the Association was disbanded, but as the vanguard managing the entry of Japanese cotton goods into the Manchurian market the Association had had great importance.

On the other hand, in the situation in which, under the Association auspices, exports of cotton cloth to China were not adequately profitable, the Osaka Cotton Spinning Company took a different route for its exports to China. That is, in 1905 it set up an agency in Tianjin for the direct sale of cotton yarn and cloth, and in 1907 raised it to the status of a branch office called the Shinsho Yoko (Xinchang Yanghang). Again, in January of 1911 it took over the Tianjin branch of the Naigai Cotton Co. (Naigai Wata). At the Tianjin branch, $80 \%$ of the business was the sale of cotton cloth, and this was done by cash sales. The Business Reports give the testimony of current Tianjin Branch staff to the effect that "Tianjin Branch operations flourished" (Latter half of 1908 and first half of 1910), while "In the Manchurian market Mie Boseki made sales through Mitsui Bussan, but because Osaka Boseki's sales were direct, there were concerns about poor sales." 42

Looking at changes from about the time of the Russo-Japanese War 
in the relative position of the weaving division of Osaka Boseki among the companies throughout the country running ancillary weaving operated by cotton spinning companies, in terms of both plant and output, from a peak in 1902 it declined until 1905. Pushed by Mie Boseki and Kanakin Cotton Cloth Company which had expanded plant activity, by Fuji Boseki which had taken over a weaving company, and by Naigai Wata, and facing the entry of Kanegafuchi Boseki into weaving (1905), the relative position of Osaka Boseki's weaving business declined. And Osaka Boseki, the weaving division of which enjoyed more than half of all sales, could not sit idly by and ignore this situation. It was against this background that the merger with the Kanakin Cotton Cloth Company took place in June 1908.

As Osaka Boseki acquired Fushimi and Shikanjima plants by the merger with Kanakin Cotton Cloth Company, the number of its looms jumped to 2,920. In number of looms, it passed Mie Boseki to regain the No. 1 position, and its product share of cotton cloth also recovered so that in 1908-09 it again exceeded 30\%. Before the merger in 1905, Kanakin's product distribution was $38 \%$ sheeting (sofu), $23 \%$ cotton drill (aya-momen), 21\% unsai, 10\% T-cloth (tenjiku-fu) and $8 \%$ duck (atsuori-momen). ${ }^{43}$ Reflecting this distribution, after the merger in Osaka Boseki's output the proportion of sheeting and duck increased. And Osaka Boseki's standing in the Korean and Chinese markets for cotton cloth was strengthened.

As we have seen, by about 1907 Japanese cotton cloth had established an impregnable position in the North China and Manchurian as well as Korean markets. In Korea, it surpassed English cottons in 1907, and after the "Unification"“ of Korea with Japan in 1910, as a result of a declining influence of Chinese merchants handling English cottons, the influx of Japanese cotton cloth became more and more dominant. In China, Japanese cottons passed American in 1911, and particularly in northern China and Manchuria, Japan showed its dominance. In the Chinese and Korean markets, however, Japan's competitive strength was mainly in sheeting and other heavy cloths, while in fine cloths like shirting and calico, England continued to lead in sales. The next target for Japanese spinning enterprises, among which export competition had been controlled under the kumiai (association) system, was to overcome English products in markets for fine cottons.

In this situation, in 1911 Osaka Boseki began the export to Korea of grey shirting woven from yarns of about no. 24 bearing the trademark "Falcon Grade A Grey Shirting" (13 lbs.). Mie Boseki did the same 
soon after ${ }^{44}$ It is said that these fine Japanese cloths

Withstood washing better than the English shirting because they were thicker and their appearance was not noticeably inferior to English shirting. And because the $12 \mathrm{lb}$. product had the same price as the English $10 \mathrm{lb}$. one, it was received well by Koreans and in a short time carved out a slice of the market from the preserve of the English product. Demand for it increased miraculously while conversely, that for the English product diminished. ${ }^{45}$

In this way, the Japanese product overcame the English one. Japanese cotton cloth thus swept the Korean market in both heavy and fine cloths, while English cottons, which in 1907 had been a match for Japanese cloths, five years later in 1913 had less than 1/10th of the market of Japanese products and in the following year, 1914, dropped spectacularly to less than 1/100th. The increase in the proportion of shirting (kanakin) in Osaka Boseki's cotton cloth output after 1911, shown in Table 4, can be assumed to be the result of this situation.

In contrast, the main exports to China were sheeting and cotton drill, while England continued to be strong in the shirting field. Overall, in cotton cloth exports to China in 1913, English products took $52.7 \%$ and Japanese, $20.7 \%$. But for Japan, the significance of the Chinese market was great, and in 1914 among cotton cloth exports, $70 \%$ went to China. In this way Osaka Boseki's weaving business came to depend quite largely on foreign markets in China and Korea.

In the Japanese market, heavier cloths for traditional Japanese type clothing like kimono were still supplied mainly by traditional smallscale weavers who were not equipped with power looms. On the other hand, the market of fine cloths continued to be dominated by imported goods. Thus, the ancillary weaving business of the Japanese spinning companies did not have full control of these two markets, and the situation brought about the efforts of spinning companies to attack these two markets. They began to enter actively into the market of imported cloths after the latter half of the first decade of the century, by producing triple-width sheeting (mihaba-kanakin) and calico. As a result, the domestic market for cotton weaves was finally captured by the Japanese weavers after 1911 when the cotton cloth import tariff was increased. Responding to these trends, Osaka Boseki stepped up its production of shirting (kanakin), particularly triple-width shirting (mihaba-kanakin), after 1902. And about 1907 shirting companies with ancillary weaving began production of cotton flannels and bleached cottons which had been specialties of the traditional weaving 
Table 7 Relation of Yarn Cost to Sale Price of Osaka Boseki's Cotton Cloth

\begin{tabular}{|c|c|c|c|}
\hline & $\begin{array}{l}\text { Sale Price of Cotton Cloth } \\
\text { Yen } / 1,000 \text { yds. } \\
\text { (A) }\end{array}$ & $\begin{array}{l}\text { Yarn Cost per } 1,000 \text { yds. of } \\
\text { Cotton Cloth (Yen) } \\
\text { (B) }\end{array}$ & $\begin{array}{c}B / A \\
\%\end{array}$ \\
\hline 1891 & 83.0 & 59.3 & 71.4 \\
\hline 1892 & 82.5 & 54.9 & 66.5 \\
\hline 1893 & 97.2 & 66.3 & 68.2 \\
\hline 1894 & 108.1 & 71.3 & 66.0 \\
\hline 1895 & 110.7 & 69.1 & 62.4 \\
\hline 1896 & 120.5 & 73.1 & 60.7 \\
\hline 1897 & 142.5 & 81.2 & 57.0 \\
\hline 1898 & 115.6 & 66.8 & 57.8 \\
\hline 1899 & 102.9 & 65.1 & 63.3 \\
\hline 1900 & 107.3 & 76.9 & 71.7 \\
\hline 1901 & 91.7 & 58.5 & 63.8 \\
\hline 1902 & 80.2 & 69.7 & 86.9 \\
\hline 1903 & 95.3 & 80.8 & 84.8 \\
\hline 1904 & 193.8 & 136.7 & 70.4 \\
\hline 1905 & 153.9 & 98.5 & 64.0 \\
\hline 1906 & 126.1 & 98.1 & 77.8 \\
\hline 1907 & 128.4 & 95.9 & 74.7 \\
\hline 1908 & 124.9 & 92.5 & 74.0 \\
\hline 1909 & 121.0 & 94.7 & 78.3 \\
\hline 1910 & 125.8 & 105.1 & 83.5 \\
\hline 1911 & 130.7 & 110.0 & 84.2 \\
\hline
\end{tabular}

Source: Osaka Boseki Kokajo

All figures are for the latter half of each year.

industry. Osaka Boseki did not enter the field of bleached cottons, but was active in the production of cotton flannels, to the extent that they took up $27.4 \%$ of company output in 1909 . Osaka Boseki developed a further diversification of cotton cloth production towards the end of the Meiji period.

Finally, let us look at the relationship between sales prices of cotton cloth and the prices of yarn used in it as shown in Table 7. From about 1894 , during the Sino-Japanese War, cotton cloth prices rose, maintaining a high level until about 1898 . During these years, prices of yarn also rose, but at a slower pace, so that yarn costs were only about $60 \%$ of the price of cloth, and sometimes even below $60 \%$. The difference between the price of $1,000 \mathrm{yds}$. of cotton cloth and the price of the yarn to make it could be as much as 40-60 yen. We can say that the profits of the weaving division after the Sino-Japanese War were high. 
Between about 1899 and 1903, however, cotton cloth prices decreased, while yarn prices did not come down significantly, so that the ratio of yarn costs increased to around the $70 \%$ level. During this interval, as a result of the increase in productivity of plant and labor, production costs decreased, yarn costs could to some extent be absorbed, but it was no doubt difficult to maintain profitability per unit of product. When profits per unit of product are not high, in order to maintain the profitability of capital, sales must be increased. It was against such a background that Osaka Boseki put such great efforts into gaining its share of foreign markets. In 1905 when the military demand boom was in full swing, cotton cloth prices took off and large profits due to the price differential between products and raw materials were reaped. But after 1906, when yarn costs rose once again, they reached the $70 \%$ level. And since wage costs were at a high level from about 1907 to 1910 , profitability was low. After the latter part of 1910, cotton yarn costs reached the $80 \%$ level. Despite a concurrent rise in the productivity of looms and labor, the pressure of raw material costs must have been pronounced. This was the situation of the Osaka Cotton Spinning Company on the eve of its merger with Mie Cotton Spinning in 1914.

\section{Concluding Remarks}

As we have seen above, from the beginning of operations of Osaka Boseki in 1883 until its merger with Mie Boseki to form the Toyo Cotton Spinning Company in 1914, there were amazing changes in product and market strategies. If we prepare a time line according to changes in main products and major markets, we can probably say that the period from commencement to about 1889 was that concentrating on sales of low counts of yarn to markets for dyed cottons in eastern Japan, the 1890 s were years concentrating on sales of no. 20 Z-twists to markets for bleached cottons, the period from the end of the $1890 \mathrm{~s}$ through the turn of the century was that of sales of thick yarns to foreign markets, the period after the middle of the first decade of the 20 th century was one of ancillary weaving and export of cloth, and that of the end of Meiji and beginning of Taisho (around 1912) was one of diversification in production of cotton cloth.

In the process of these changes in strategy, the products developed and markets opened by Osaka Boseki in each period brought about the innovation for Japan's spinning industry. In this sense, the innovative entrepreneurial activity of Osaka Boseki must be highly evaluated, and we can probably say that the Company's business activities entitle 
it to be called the "leading company" in the spinning industry of the Meiji period (1867-1912). And these constant efforts for renovation and innovation also can be said to be the most prominent factor in Osaka Boseki's somehow being held back as just one of many important spinning companies in the Meiji period.

As we have seen, however, rather than being aimed offensively at expanding on its superiority over other enterprises in existing lines of production, Osaka Boseki's changes in product and market strategy were of a defensive nature, aimed at extricating itself from defeats in those existing lines of endeavor. And Osaka Boseki's innovative strategies were soon taken over by other enterprises, plunging it into new competition. In almost all products and markets (with the possible exception of the Chinese and Korean markets for cotton cloth) tested by Osaka Boseki, it was unable to reap the profits of an innovator for long, and was obliged to grope for new escape routes one after the other. In other words, in the case of many of the product and market strategies taken in various periods by Osaka Boseki, they were an unavoidable choice in the current business environment in which the company found itself engulfed.

If this was so, what was the basic cause which made these continual changes in product and market strategies of Osaka Boseki inevitable, that is, the cause of the loss of its competitive strength? Were there problems in production technology or plant management? Was there inflexibility in the financial makeup of the company which influenced investment in plant? Was there a lack of leadership in management?

A strong impression resulting from this tracing of the changes in product and market strategies of Osaka Boseki is that there may have been some weakness in the Sales and Business Divisions of the company. We can give some evidence supporting this impression. First, it is impossible to single out from among the owners or managers of Osaka Boseki any person who actively led the sales or business activities of the company. At its inception, the old feudal lords (exDaimyo, Kazoku-so) were the biggest investors, holding $38 \%$ of the capital in January of 1884 , while Osaka merchants with $31 \%$ and Tokyo merchants with $29 \%$ were also large shareholders. Among the Osaka merchants, there were many connected with the cotton and dry goods trades, and among the Tokyo shareholders, those dealing in yarn and dry goods as well as those shipping raw silk from Yokohama. Eiichi Shibusawa, who was the organizer of the company's formation, expected these merchants connected with the textile trade not only to act as investors but also to exert their efforts in the sale of Osaka 
Boseki's products. As we have seen above, because Tokyo was expected to become the main sales outlet, the onus placed on the Tokyo merchants was particularly heavy, and it can be assumed that they played a definable role in the initial business endeavors. In subsequent development, however, these Tokyo merchants gradually withdrew from the ranks of major shareholders. Concurrently, the proportion of shares held by Osaka merchants rose, but the ratio of ownership by stock brokers and others both of whom did not have much interest in the management of Osaka Boseki also gradually rose, and the active role in management of merchants connected with the textile trade declined. Those from the textile field who entered the managerial group of Osaka Boseki, other than Fusajiro Abe and Masajiro Tatsuki who came in after the merger with Kanakin Seishoku in 1908, were only Seiichiro Saeki (Chairman of the Board of the Osaka Cotton Thread and Cloth Exchange) as Director, Ichitaro Abe, Shinzaburo Akima and Shojuro Shibuya as Auditors, and Seizo Kamata and Rihei Kawamura as Sales Managers.

There are two factors which can be considered pertinent in the failure of Osaka textile merchants to take a stronger role in the management of Osaka Boseki. One is a change in the relationship with the Naigai Cotton Company. This company, trading in raw cotton, was set up by influential Osaka raw cotton merchants in 1887, and its leading investors were Jutaro Matsumoto, Shinzaburo Akima, Shosaburo and Shojuro Shibuya, and Seizo Kamata, most of whom were also in Osaka Boseki. It can be supposed that these people connected with the cotton trade conceived the business plan for the Naigai Cotton Company on the basis of their close links with Osaka Boseki. Until about 1900, in fact, Naigai Wata and Osaka Boseki had close relations in the procurement of raw cotton and related financial matters. Yet, from the $1890 \mathrm{~s}$ into the new century, the management of Naigai Wata is said to have been unstable. ${ }^{46}$ This probably had an effect on Osaka Boseki's business. Moreover, in the years after 1905 Naigai Wata ventured into spinning and enhanced its independence. As well, in 1898 Osaka Boseki's Sales Manager, Rihei Kawamura, who had demonstrated his commercial ability in the purchase of raw cotton for Osaka Boseki, transferred to become director and sales manager of Naigai Wata. In this way, persons connected with the cotton trade in Osaka Boseki who had helped to establish Naigai Wata as a trading company cooperating with Osaka Boseki also helped to weaken its links with Osaka Boseki, and this was no doubt one means by which weakness was brought into Osaka Boseki's commercial affairs. 
Second was the withdrawal from the main group of directors of Denzaburo Fujita and Jutaro Matsumoto who had cooperated with Shibusawa as major investors from the Osaka side at the establishment of Osaka Boseki. Taking advantage of their position as the most powerful business leaders in those days in Osaka, Fujita and Matsumoto greatly contributed to raise the initial capital funds for Osaka Boseki from Osaka merchants in a variety of fields who were reluctant to invest in a new business such as cotton spinning. Fujita, who had been the first head of Osaka Boseki, left this position as early as 1887, and also rapidly disposed of his shares which had made him the 10th largest holder while he had held the position of head. Subsequently, Matsumoto became head and President, but Matsumoto also resigned in 1889. On the transfer of the presidency from Matsumoto to Takeo Yamanobe, there seems to have been some discord in the managerial echelons, and Eiichi Shibusawa testified as follows.

There were also troubled times for the Osaka Cotton Spinning Company. Perhaps finding it difficult to ensure these, Yamanobe dropped in to Tokyo one day, and it having got to the point that even the indefatigable Yamanobe was unexpectedly ready to quit Osaka Boseki, although I was not unaware that the spinning industry was in dire straits as the result of the current economic situation, since such action would pop the bubble which our efforts had created so far, I said that I was irrevocably opposed, and gave him words of encouragement. ${ }^{47}$

Again, Katsumasa Okamura, a spinning engineer of the company at the time, adds the following.

In 1897 the reaction to the postwar boom set in, and with the fall in the value of silver and the upheaval in the exchange rate with China, there were troubled times for the spinning industry and Osaka Boseki also turned out big losses. The Osaka directors around the current President, Jutaro Matsumoto, who had been hostile to the real power of Mr. Yamanobe in the company, began so say that because they were losing with Yamanobe as chief, they would like to have him resign at this time. Defamed and attacked in various ways at shareholders' meetings, Mr. Yamanobe was embittered and seems to have wanted to quit the company, and even consulted with me. It was probably about this time that he went to Mr. Shibusawa's residence to ask to resign. But in the following year, when the situation became disadvantageous for President Matsumoto's group, they were in turn attacked, and in $1898 \mathrm{Mr}$. Yamanobe became 
president instead, and with the commercial recovery of 1899 considerable profits were made and $\mathrm{Mr}$. Yamanobe was triumphant. ${ }^{48}$

Takeo Yamanobe, who was the first Japanese technical expert of cotton spinning trained at a British factory, had been working as a virtual top manager of Osaka Boseki. As has often been pointed out, the appointment of Takeo Yamanobe as president was significant as the beginning of a change from the main form of Meiji period stock companies in which the major shareholders acted concurrently as directors to a form in which professional managers were hired by the company. When Matsumoto retired, he pointed out in the following words that the time had come when a professional manager should be appointed.

I have held the post of president for more than 10 years, but today when the industry has advanced conspicuously, it has become difficult for someone like myself who has interests in other companies to act as president in name only. From now on, someone must be chosen as president who can devote himself to this company alone and supervise management and production himself. ${ }^{49}$

The withdrawal from participation in Osaka Boseki of Fujita and Matsumoto who had played such a major role in rallying the Osaka merchants in the formative period of Osaka Boseki, while on the one hand brought about the appointment of hired professional managers, may have also spread the passivity of Osaka merchants towards Osaka Boseki which was said to have "made the recruitment of shareholders in Osaka so difficult." ${ }^{50}$ After the appointment of Yamanobe as president, as we have seen, Osaka Boseki shifted the emphasis from the export of yarn to ancillary weaving, and strengthened its dependence on cloth exports and foreign markets. This withdrawal from internal markets was probably not unrelated to the change in the management team.

Not only in sales and business matters, but also in administration, Osaka Boseki had problems. Let us look at one example which illustrates this. A staff member concerned with the business side who entered the company in 1905 stated the following.

When I entered the company, the internal atmosphere was gloomy. The company's organization was in such disorder that one superintendent was purchasing and in charge of accounting and someone named Oguri misappropriated 500,000 yen and was sentenced to three years' imprisonment with hard labor. As Mr. Shibusawa wielded great authority in Osaka Boseki and Mie Boseki, at 
accounting times someone would always go to consult him. As it was decided that something had to be done about Osaka Boseki's disorder, Branch Manager Sasaki of the Daiichi Bank was brought in as Superintendent. On investigating, Sasaki found that the accounts were all of the old-fashioned type, and as he thought this inadequate, using school graduates he set about reforming the system. ${ }^{51}$

Another staff member connected with the business end who joined the company in July of the same year (straight out of school) testified that:

In August of 1905 I was sent to my new post at the Tianjin branch of Osaka Boseki. The Branch Manager was a relative of Mr. Takeo Yamanobe, but because he had been sent home ill and was recuperating, I was handling the office business alone. Because Osaka Boseki's accounting system was of the old-fashioned type when I joined the company, a superintendent Sasaki of the Daiichi Bank had come and was pursuing reforms, and because it was thought that those of us who were fresh out of school knew everything, we prepared ledgers, day-books and vouchers. I took these new means of accounting with me to Tianjin. The Branch manager soon returned to his post, but our ideas did not agree.

At the time, Osaka Boseki was cash poor and had been given a loan of 600,000 yen by the Naigai Wata Company, and Mr. Sasaki apparently joined the Company to oversee it (the loan). ${ }^{52}$

The Oguri embezzlement case mentioned in the first quotation occurred in 1904. A staff member connected with accounting embezzled 300,000 yen, and more than 190,000 of which was lost to the Company. In the latter half of 1904, the expedient was adopted of docking half of the emoluments of those who accepted responsibility. The embezzled sum of 300,000 yen was $8 \%$ of current total assets and about $20 \%$ of liquid assets, so a single wrong by one staff member concerned a huge amount. This would seem to show that there were systemic deficiencies in the business management system. The appointment of Kiyomaro Sasaki, Yokkaichi Branch Manager of the Daiichi Bank, as a superintendent (December, 1903), mentioned in the staff members' statements, and the reappointment of Tatsutaro Kumagai, Osaka Branch Manager of the same bank, as a director (March, 1905) can be considered a manifestation of the Bank's concern regarding the management system of Osaka Boseki, for which it was a major financier. 
And such things as the testimony of staff members to the effect that "the Company's organization was in disorder", and "the accounting system was of the old-fashioned type," as well as the fact that a new entrant to the Company took over responsibility for an important foreign branch of Osaka Boseki only one month after joining the Company - these things allow us to imagine what the business organization of Osaka Boseki was like.

In any case, the Osaka Cotton Spinning Company merged with the Mie Cotton Spinning Company in June of 1914 to become the Toyo Spinning Company. The conditions of the merger was unequal, with a ratio of five to four in Mie Boseki's favor; that is, for four shares of stock in Mie Boseki the shareholder received five in the new company, but Osaka Boseki shareholders had to put up five shares in order to receive five in Toyo Boseki. The line-up in the new company, moreover, was five directors for Mie Boseki and only two for Osaka Boseki. ${ }^{53}$ These conditions of merger also reflected Osaka Boseki's weakness as an enterprise.

\section{Notes}

1. From the "Seizo Jikkyo" (State of Production) in the Osaka Boseki Kokajo (Business Report of the Osaka Cotton Spinning Company).

2. Katsumasa Okamura, "Boseki Kaikyu Dan" (Spinning Recollections), in Shibusawa Eiichi Denki Shiryo (Biographical Materials Concerning Eiichi Shibusawa), vol. 10, p. 80.

3. Heita Kawakatsu, "Meiji zenki ni okeru naigai men kankei-hin no hinshitsu"(The Quality of Cotton Products in Early Meiji), in Waseda Daigaku Seiji-Keizai-gaku Zasshi (Journal of Politics and Economics of Waseda University), nos. 250, 251, 1977.

4. "Kogyo Iken" (Opinion of Industry), vol. 12, reprinted in Meiji Zenki Zaisei Keizai Shiryo Shusei (Collection of Historical Materials on Finance and the Economy in Early Meiji), vol. 18 (2), pp. 487-8.

5. Ibid., p. 488.

6. "Menshi shudan-kai kiji" (Record of the Cotton Yarn Consultative Meeting), in Meiji Zenki Sangyo Hattatsu-shi Shiryo (Historical Materials on the progress of Industry in the Early Meiji Period), vol. 8 (4), pp. 29-30, 106.

7. Ibid., pp. 15-16. 
8. "Kogyo Iken", op. cit., pp. 488-9.

9. "Boseki menshi no zento" (The Outlook for Spun Cotton), in Rengo Boseki Geppo (Associated Spinners' Monthly), no. 4, 1898.

10. Naosuke Takamura, Nihon Boseki-gyo Shi Josetsu (Introduction to the History of the Japanese Spinning Industry), Jo (vol. 1), p. 164.

11. Rengo Boseki Geppo, no. 16 (1890) and no. 28 (1891).

12. Ibid., no. 12, 1892.

13. Naosuke Takamura, "Osaka Boseki Kaisha" (The Osaka Cotton Spinning Co.), in Kazuo Yamaguchi, ed., Nihon Sangyo Kinyu Shi: Boseki Kinyu Hen (History of the Financing of Japanese Industry: Spinning), 1970, pp. 354-5.

14. Dai-Nippon Menshi Boseki Dogyo Rengo Kai Hokoku (Reports of the Greater Japan Cotton Spinners' Association), nos. 10-15.

15. Ibid., no. 41.

16. Mitsuhaya Kajinishi, Gendai Nihon Sangyo Hattatsu-shi 9: Sen'i jo (History of the Progress of Modern Japanese Industry 9: Textiles, vol. 1), Furoku Tokei-hyo (Statistical Appendix), p. 50.

17. Takamura, Nihon Boseki-gyo Shi Josetsu, Jo (vol. 1) p. 212, Ge (vol. 2) p. 82.

18. Dai-Nippon Menshi Boseki Dogyo Rengo Kai Hokoku, nos. 5964.

19. Takamura, Nihon Boseki-gyo Shi Josetsu, Ge p. 115.

20. Dai-Nippon Menshi Boseki Dogyo Rengo Kai Hokoku, no. 118.

21. Asahi Shimbun (Asahi Newspaper), ed., Nihon Keizai Tokei Sokan (Cumulative Statistics on the Japanese Economy), 1930, p. 420 .

22. "Osaka Daigaku Kindai Bukka-shi Kenkyu-kai" (Osaka University Association for Research on the History of Modern Prices), ed., "Osaka oroshi-uri bukka shiryo (7)" (Materials on Osaka Wholesale Prices, vol. 7), in Osaka Daigaku Keizai Gaku (Osaka Economic Papers, vol. 31, no. 4, 1982.

23. Takamura, Nihon Boseki-gyo Shi Josetsu, Jo p. 235.

24. Hatsu Murakami, "Kanegafuchi Boseki Kaisha" (The Kanegafuchi Spinning Co.), in Yamaguchi, Nihon Sangyo Kinyu Shi: Boseki Kinyu Hen, p. 503, Naosuke Takamura "Settsu Boseki Kaisha" (The Settsu Spinning Co.), in ibid., p. 602, and Takamura, Nihon Boseki-gyo Shi Josetsu, Ge p. 115.

25. Dai Nippon Menshi Boseki Dogyo Rengo Kai Hokoku, no. 66.

26. Takamura, Nihon Boseki-gyo Shi Josetsu, Ge p. 115. 
27. Mitsuhaya Kajinishi, op. cit., Furoku Tokei-hyo, p. 50.

28. Taichi Kinugawa, Honpo Menshi Boseki Shi (History of the Cotton Spinning Industry in Japan), 1937, vol. 6, p. 190.

29. "Osaka Boseki Kabushiki Kaisha Enkaku-shi" (History of the Osaka Cotton Spinning Co. Ltd.), in Shibusawa Eiichi Denki Shiryo, vol. 10, p. 94.

30. Kamenosuke Fujino, "Honpo menpu jigyo no shorai" (The Future of Japan's Cotton Cloth Business), in Dai Nippon Menshi Boseki Dogyo Rengo Kai Hokoku, no. 112.

31. Ichiro Tonoi, "Meiji nendai ni okeru boseki ken'ei shokufu" (3) (Weaving Ancillary to Spinning in the Meiji Period, 3), in Keizai Riron (Theory of Economies), no. 74, 1963.

32. Ibid.

33. Ibid., (2), Keizai Riron, no. 73, 1963, p. 104, and Teiji Yamauchi, "Osaka-shi ni okeru yushutsu kikai menpu chosa hokoku" (4) (Report on the Survey on Exports of Machine-woven Cotton Cloth in Osaka City, 4), Dai Nippon Boseki Rengo Kai Geppo (Monthly of the Greater Japan Spinners' Association), no. 163, pp. 3-6.

34. Tonoi, op. cit., (2), pp. 107-8, and Kinugawa, op. cit., vol. 6, pp. 177-8.

35. Takamura, Nihon Boseki-gyo Shi Josetsu, Ge pp. 88-9, and Yamauchi, op. cit., (3), Geppo no. 162, p. 5.

36. Tonoi, op. cit., (2), p. 104, and Yamauchi, op. cit., (5), Geppono. 164, p. 5.

37. "Chosen Menpu Shi" (History of Korean Cotton Cloth), in Shibusawa Eiichi Denki Shiryo, vol. 10.

38. "Hishida Itsuji Shi dan" (A Conversation with Mr. Itsuji Hishida), Toyo Boseki Shashi Shiryo (Materials for the Company History of Toyo Spinning), no. 18, 1948.

39. Otojiro Matsuo, "Waga kuni Shokogyo no gendai oyobi shorai" (The Present and Future of Japan's Commerce and Industry), in Shibusawa Eiichi Denki Shiryo, vol. 10, pp. 519-24.

40. Ibid.

41. Takamura, Nihon Boseki-gyo Shi Josetsu, Ge p. 189.

42. "Hishida Itsuji Shi dan", op. cit.

43. Menshi Boseki Jijo Sanko-sho (Information on the State of Cotton Spinning), 1905 edition.

44. "Chosen Menpu Shi”, op. cit., p. 509.

45. Ibid.

46. Naosuke Takamura, "Naigai Wata Kaisha" (The Naigai Cotton 
Co.), in Yamaguchi, op. cit., p. 242.

47. Yonekichi Uno, ed., Yamanobe Takeo Kun Shoden (A Short Biography of Takeo Yamanobe), Furoku (Appendix), pp. 6-9.

48. "Okamura Katsumasa Shi danwa" (Conversations with Mr. Katsumasa Okamura), in Shibusawa Eiichi Denki Shiryo, vol. 10, p. 50 .

49. Osaka Boseki Kabunushi Sokai Ketsugi Roku (Record of the Resolutions of the General Meetings of the Shareholders of the Osaka Cotton Spinning Company), Nov. 12, 1898.

50. Takamura, Nihon Boseki-gyo Shi Josetsu, Jo p. 73.

51. "Hishida Itsuji Shi dan", op. cit.

52. "Nakayama Hideichi Shi kaiko-roku" (Memoirs of Mr. Hideichi Nakayama), Toyo Boseki Shashi Shiryo, no. 19, 1948.

53. Toyo Boseki Nanaju-nen Shi (The 70-year History of the Toyo Spinning Company), 1953, pp. 139-150.

Translated by Donald Burton 